\title{
The Inclusion of Organ Within the Concert Band Instrumentation with an Annotated Listing of Original Works for Concert Band and Organ
}

Matthew Justin McCurry

West Virginia University, mjm0046@mix.wvu.edu

Follow this and additional works at: https://researchrepository.wvu.edu/etd

\section{Recommended Citation}

McCurry, Matthew Justin, "The Inclusion of Organ Within the Concert Band Instrumentation with an Annotated Listing of Original Works for Concert Band and Organ" (2019). Graduate Theses, Dissertations, and Problem Reports. 4066.

https://researchrepository.wvu.edu/etd/4066

This Dissertation is protected by copyright and/or related rights. It has been brought to you by the The Research Repository @ WVU with permission from the rights-holder(s). You are free to use this Dissertation in any way that is permitted by the copyright and related rights legislation that applies to your use. For other uses you must obtain permission from the rights-holder(s) directly, unless additional rights are indicated by a Creative Commons license in the record and/ or on the work itself. This Dissertation has been accepted for inclusion in WVU Graduate Theses, Dissertations, and Problem Reports collection by an authorized administrator of The Research Repository @ WVU.

For more information, please contact researchrepository@mail.wvu.edu. 
The Inclusion of Organ Within the Concert Band Instrumentation with an Annotated Listing of Original Works for Concert Band and Organ

\author{
Matthew J. McCurry
}

\title{
Research Project submitted to the College of Creative Arts at West Virginia University
}

\section{in partial fulfillment of the requirements for the degree of \\ Doctor of Musical Arts in Conducting}

\author{
Scott Tobias, D.M.A., Chair \\ Kym Scott, D.M.A. \\ Evan MacCarthy, Ph.D. \\ Lee Blair, M.F.A. \\ School of Music
}

Morgantown, West Virginia

2019

Keywords: Concert Band, Organ, Instrumentation, Composition, Music Publishers (c)2019 Matthew McCurry 


\begin{abstract}
The Inclusion of Organ Within the Concert Band Instrumentation with an Annotated Listing of Original Works for Concert Band and Organ
\end{abstract}

\author{
Matthew J. McCurry
}

There is a very limited amount of information regarding musical works available for concert band and organ. When used in conjunction with the concert band, the organ can serve different roles such as soloist with concert band accompaniment, a complimentary texture within the concert band sound, or the means for creating a majestic impact point or grand finale with full forces of organ and concert band combined. Although there are only a small number of works that fall into this category, composers continue to write works for concert band that include organ in the instrumentation. This document is an attempt at an exhaustive list of original publications for concert band that include organ within the work's instrumentation. A request was sent to all publishers of print music within the Music Publishers Association of the Unites States (MPA) to find works that fit into this seemingly obscure category. Of the 331 requests sent, 127 responses resulted in 25 publishers with works of this nature. The resulting 68 pieces for concert band that include organ are listed with title, composer, publisher, publication year, duration, ensemble difficulty level and type, and organ difficulty level and type. In addition, a selection of composers whose works met these criteria were surveyed as to what role they found the organ fulfilling when used within the instrumentation, whether substitution or omission was preferred, and if omission of this instrument changed the intent of the work. 


\section{ACKNOWLEDGEMENTS}

I am grateful to have had the opportunity to continue my education at West Virginia University. It has been an honor and privilege to learn from outstanding professors and the distinguished conducting faculty of Dr. Scott C. Tobias, Dr. Kym Scott, and Dr. Mitchell Arnold.

I wish to acknowledge, with deepest gratitude, the expertise and guidance of my doctoral committee members, Dr. Scott C. Tobias, Dr. Kym Scott, Dr. Evan MacCarthy, and Professor Lee Blair, all of whom showed great kindness and support throughout this study and completion of this degree. I am especially indebted to Dr. Tobias for sharing his wisdom, talent, and time with me and allowing me to share the podium throughout this entire process.

I would also like to thank Dr. Marshall Forrester for his guidance and encouragement in pursuing an advanced degree. His leadership, dedication, and example in furthering excellence in collegiate band programs laid a solid foundation for this author to travel down this path.

The daily encouragement and cooperation of my fellow officemates, Brandon Carbonari, Cody Lassinger, Brandon Buterbaugh, and Lamar Riddick made every day seem just a little less stressful, and for that I am very grateful.

Finally, I have been blessed with unending support from my parents, Mr. James R. and Dr. Alice H. McCurry, whom, without their unwavering faith, encouragement, and love, the completion of this degree would not have been possible.

\section{Soli Deo Gloria!}


Page

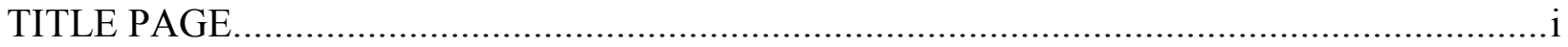

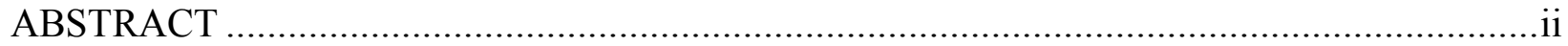

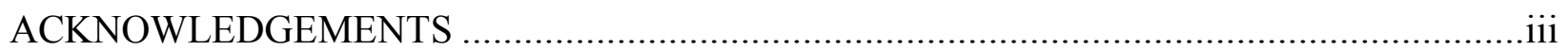

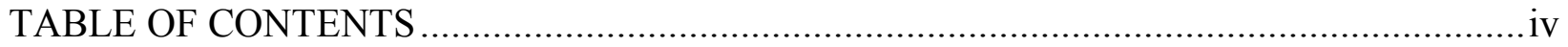

LISTING OF CONTENTS BY COMPOSER AND TITLE..................................................

INTRODUCTION

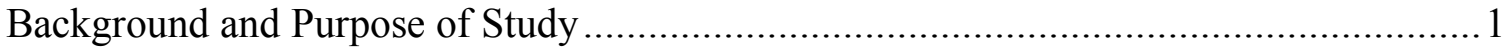

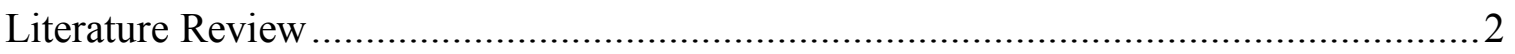

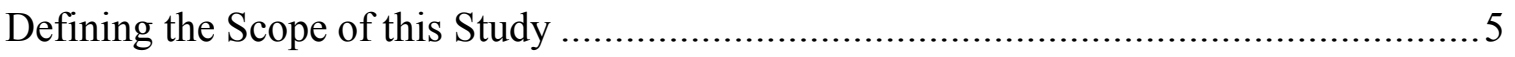

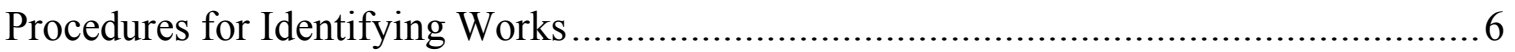

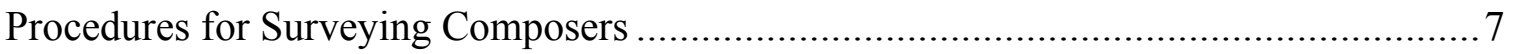

Description of Entry Formatting ........................................................................ 8

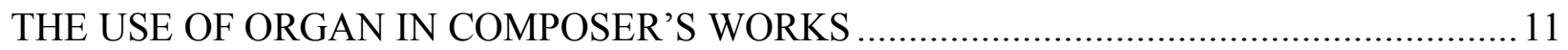

ANNOTATED LISTING OF PIECES MATCHING CRITERIA............................................... 16

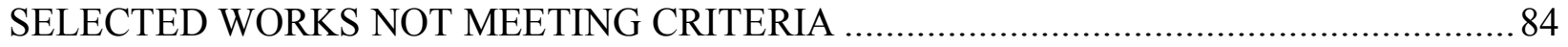

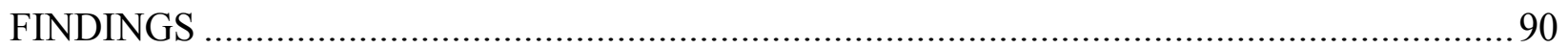

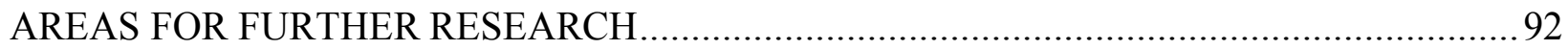

APPENDICES

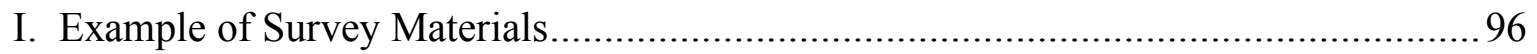

II. Listing of Publishers with Works for Concert Band and Organ ................................. 100

III. Listing of Publishers with No Works for Concert Band and Organ ........................... 102

IV. Listing of Publishers Unable to Contact................................................................... 104 


\section{LISTING OF CONTENTS BY COMPOSER}

\section{Abigaña, Brett}

Symphony No. 1

Amis, Kenneth

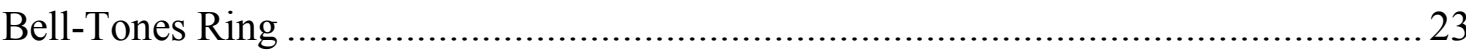

\section{Ayres, Jesse}

Akedah

Veni Emmanuel.

\section{Basford, Daniel}

Night Journey

Songs and Refrains

Blahnik, Joel

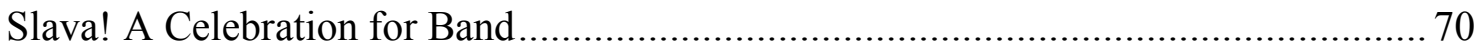

\section{Bocook, Jay}

Gloriana

\section{Boss, Andrew}

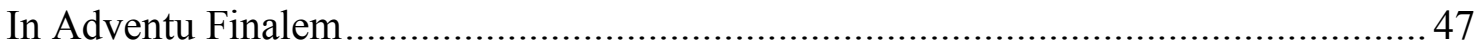

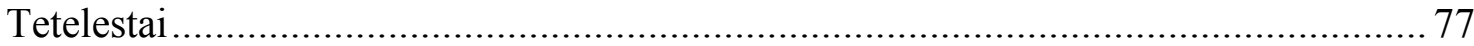

Brookes, Phillip Andrew

Festival Fanfare

\section{Brown, Raynor}

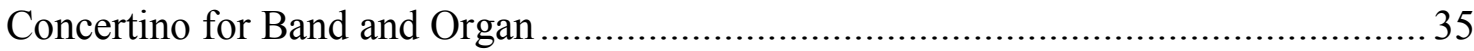

\section{Bulla, Stephen}

Lauda Anima

\section{Daugherty, Michael}

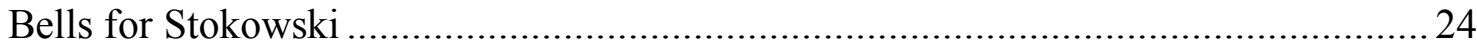

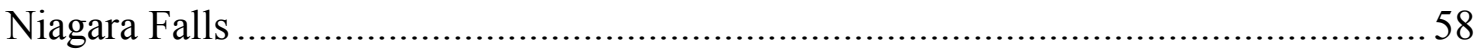

Day, Kevin

$\mathrm{JR}$ 
de Meij, Johan

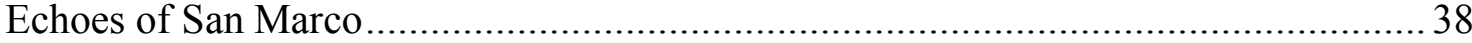

Polish Christmas Music ............................................................................... 62

Freund, Don

Navitas!

56

\section{Gillingham, David}

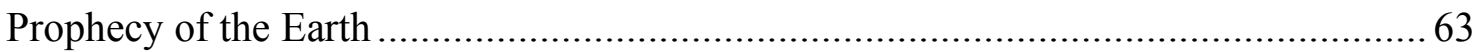

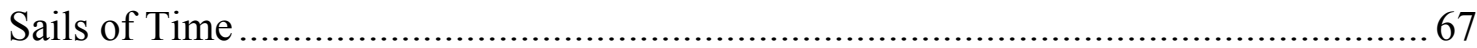

\section{Giroux, Julie}

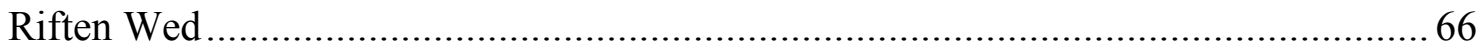

\section{Gould, Morton}

Cheers! A Celebration March ................................................................................ 31

\section{Grainger, Percy}

The Power of Rome and the Christian Heart....................................................... 79

Ye Banks and Braes O’ Bonnie Doon ..................................................................... 83

\section{Grantham, Donald}

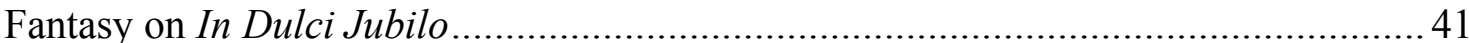

\section{Harrison, Tyler}

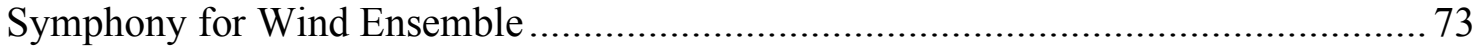

\section{Hoshide, Takahashi}

A Christmas Carol Fantasy ......................................................................... 17

\section{Jager, Robert}

Meditations on an Old Scottish Hymn

\section{Kallman, Daniel}

Fantasia Variations on Eternal Alleluias

\section{LaBounty, Anthony}

Salmo de la Rinascita 
Mahpar, Steve

Archangel

Mahr, Timothy

Fanfare and Grand March 39

Margolis, Bob

Terpsichore 76

Markowski, Michael

The Divine Right of Kings.......................................................................... 78

Maslanka, David

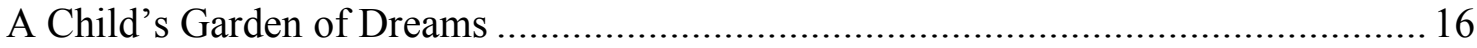

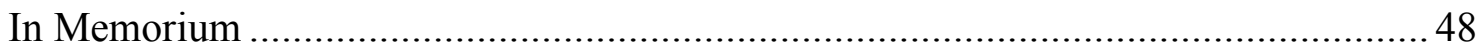

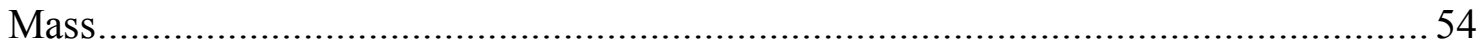

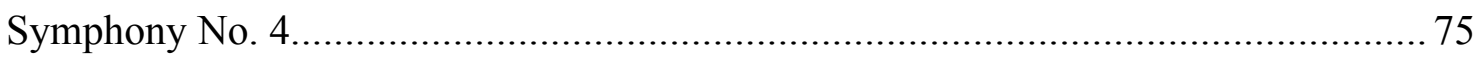

\section{McCullough, Amanda}

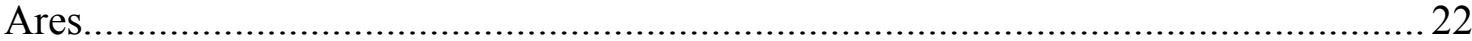

\section{Melillo, Stephen}

Finest Hour!

\section{Nelson, Ron}

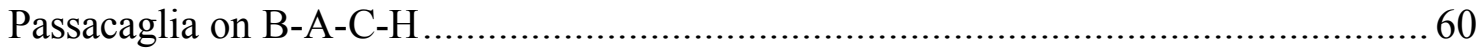

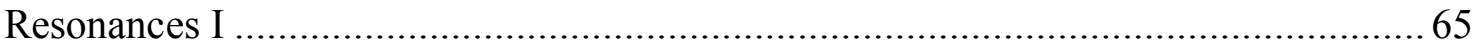

Reed, Alfred

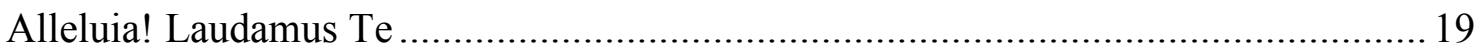

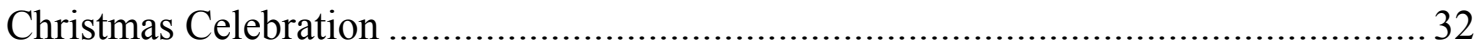

Reineke, Steven

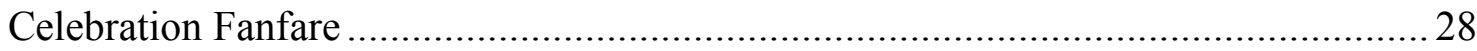

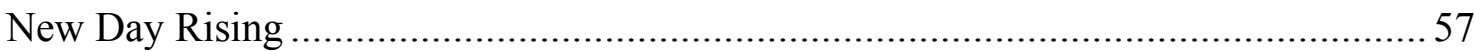

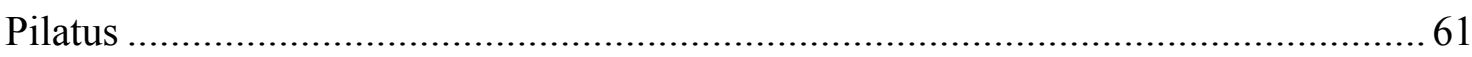

\section{Rhea, Timothy}

Captain Majesty: A Celebration Hymn for Symphonic Band .................................. 27 


\section{Rumsey, Tim}

Variations on God of Our Fathers ............................................................ 80

Schelle, Michael

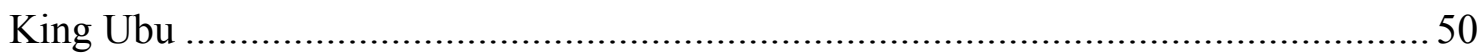

\section{Schoonenbeek, Kees}

Sonata Da Chiesa for Organ and Concert Band................................................. 71

\section{Sparr, D.J.}

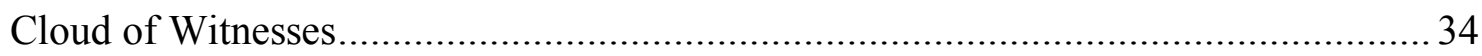

\section{Smith, Claude T.}

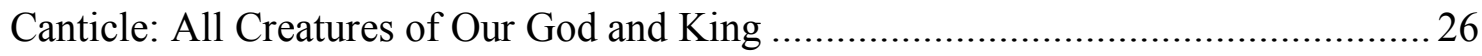

\section{Stamp, Jack}

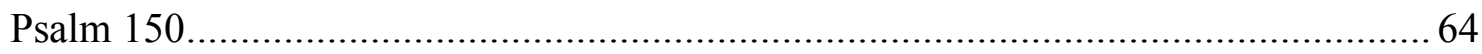

\section{Stephenson, James}

Celebration Overture for Wind Ensemble ........................................................... 30

\section{Stravinsky, Igor}

Circus Polka

\section{Swearingen, James}

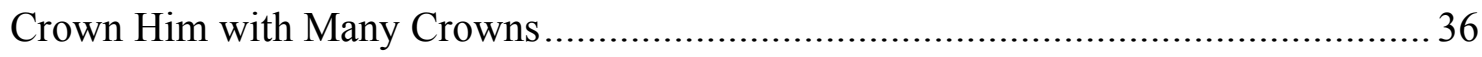

Lead On, O King Eternal .......................................................................... 52

\section{Ticheli, Frank}

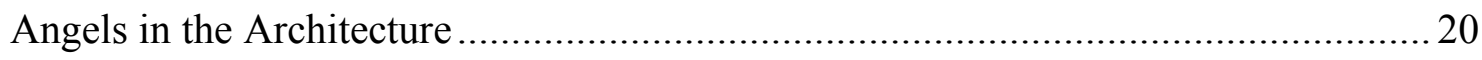

\section{Van der Roost, Jan}

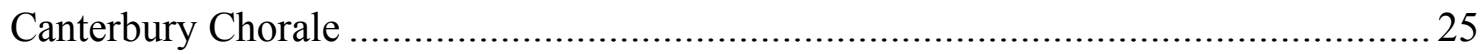

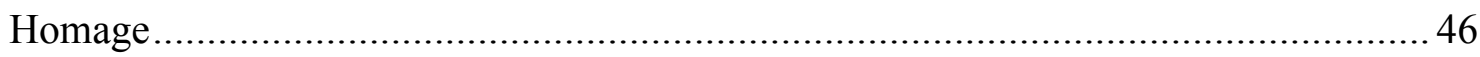

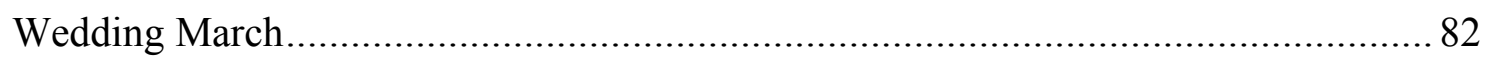

\section{Wasson, John}

Festival Fanfare for Christmas..................................................................... 43 


\section{Whitacre, Eric}

Deep Field

Wood, Hayden

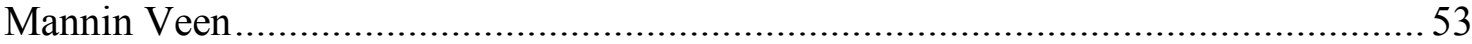

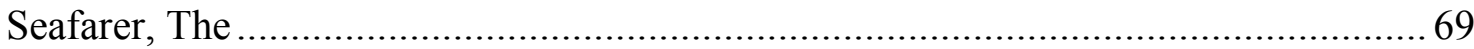

Yagisawa, Satoshi

Celebration Fanfare for Organ and Concert Band ................................................... 29

\section{SELECTED QUALITY WORKS THAT FALL SHORT OF THE DELIMITATIONS OF} THIS STUDY

\section{Loudová, Ivana}

Concerto for Wind Orchestra, Percussion, and Organ ........................................ 85

Maslanka, David

Concerto for Piano, Winds, and Percussion ................................................... 86

Pütz, Marco

Concerto for Organ, Winds, and Percussion....................................................... 84

Weinberger, Jaromír

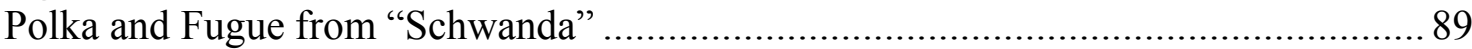

Yi, Chen

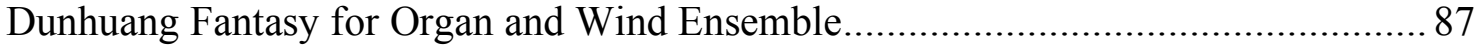

Zimmerman, Bernd Alois

Musique pour les Soupers du Roi Ubu............................................................. 88 


\section{INTRODUCTION \\ Background and Purpose}

Compositions for the concert band that include organ within the instrumentation are seemingly rare amongst the vast collection of works for the wind band. When searching catalogs and library holdings, discovering and locating these works also proves very difficult because of the inability to search by instrumentation within a collection. The absence of vital information such as the difficulty level of the piece, the difficulty level of the organ part, or the overall instrumental forces required for performance could cause difficulty in making programming decisions. Because of this, although they may find themselves in a venue with a quality instrument, conductors might not actively seek works that would include the use of the organ.

In a parallel study with works for concert band and chorus, a study after which this research is modeled, Dr. W. David Richardson describes this as a "cyclic problem."1 He describes this repeating pattern stating, "the lack of information about the compositions discourages their performance, the lack of performances discourages their composition, [and] the lack of composition discourages gathering information about the pieces." The same cyclic pattern could apply here, however there is another factor involved when considering works for concert band and organ - the availability of a quality organ.

When selecting a piece for concert band that includes the organ, should a conductor not have access to a quality organ, should omission or substitution be considered? Many composers have intentionally marked the part as optional and cross-cued organ parts within the ensemble to make the work playable without the organ. However, should an electronic substitute present itself, whether an electronic organ or keyboard, would composers consider this type of

\footnotetext{
${ }^{1}$ W. David Richardson, "Original Compositions for Full Concert Band and Chorus Published in the United States." (DMA diss., The University of Georgia, 2004).
} 
substitution adequate to pursue the work's intent? Some composers may actually prefer omission rather than an inadequate substitution. When considering this type of programming, these questions should not be left unanswered.

To help aid conductors that find themselves in this situation, this document contains an annotated listing of works for concert band and organ published at the time of the study. Inevitably (and with highest hopes), there will be many more added to this listing. In addition, to answer some of the questions posed, this document contains results from a composer survey in response to the use of organ within their compositions and their thoughts on appropriate substitution or omission of the organ part. By bringing an awareness to the availability of such compositions, hopefully it will encourage the performance of these works and even the compositions of new works for this medium.

\section{Literature Review}

There have been few studies about the use of organ in an orchestral setting and in transcriptions for concert band, but, at present, there appears to be no research into the purpose of the organ as a voice in the concert ensemble, nor does an annotated listing exist that allows one to discover these pieces. Databases have been created that allow for sorting by genre and providing a listing of instrumentation for an individual work, however, a method to find concert band pieces that include organ has not been devised other than the conductor's ability to look at the instrumentation list on the musical score or on a publisher's website. 
A thesis project conducted by Johanna Marie Kremer in 1974 at Washington University entitled "The Organ in Symphonic Ensemble"2 focused on the organ's use in the orchestra. In her study, she includes an appendix listing pieces available for orchestra and organ.

In a distantly related dissertational study entitled "The Pipe Organ as Inspiration for Wind Band Transcriptions with a Transcription of Charles-Marie Widor's Symphony No. 5 in F minor and a Conductor's Guide to Rehearsal and Performance," author, John Lopez, relates the pipe organ to the wind band by instrument and timbre similarities, and in doing so, demonstrates the similarities between timbres and sonorities of the concert band. While Lopez's study deals mainly with the ability to transcribe organ music as concert band literature, his discussion of tone, timbre, and orchestration techniques are beneficial to understanding organ characteristics and how they relate to the modern concert band.

There exist comprehensive indexes of concert band works such as The Instrumentalist Company's Band Music Guide. ${ }^{3}$ This valuable publication provides a categorized list of concert band works published through 1989 and lists the title, composer, and publisher for each composition. However, being limited to only this information, there is no way to explore instrumentation to see what might be available for concert band and organ. In Section "C" of the book, under "Miscellaneous Solos," one concerto is listed for organ and band. ${ }^{4}$ Had the word organ not been in the title, there would have been no way to identify this piece as inclusive of an organ part.

\footnotetext{
2 Johanna Marie Kremer, "The Organ in Symphonic Ensemble,” (Ph.D. diss., Washington University in St. Louis, 1974).

${ }^{3}$ Band Music Guide, (Northfield, IL: The Instrumentalist Publishing Company, 1989).

${ }^{4}$ Raynor Brown, Concerto for Organ and Band
} 
Frank Cipolla and Donald Hunsberger compiled a number of essays on the development of the wind ensemble in their book The Wind Ensemble and its Repertoire. ${ }^{5}$ The appendices of this book contain the repertoire of the Eastman School Symphony Band and Wind Ensemble from 1935-1992. While very informative of the types and development of wind ensemble programs, the information provided only lists title, composer, conductor, and guest soloists. Although works identified in this study were listed, none gave indication to whether or not organ was used. While an amount of quality literature is represented in these listings, these works are limited to conductor selection and cannot be used as a comprehensive index.

Frank Battisti, William Berz, and Russ Girsberger produced a resource guide in 2014 entitled Sourcebook for Wind Band and Instrumental Music ${ }^{6}$ that proved to be helpful in locating resources for research on this subject. The general resources listed in the first part of the book not only contain valuable information for band directors, but lists current information for music publishers that publish band music. Specific resources include composer websites and current (as of 2014) research into instrumental music. One work for concert band and organ, Michael Daugherty's Niagara Falls, was listed as having organ within the instrumentation.

\footnotetext{
${ }^{5}$ The Wind Ensemble and its Repertoire, ed. Frank Cipolla and Donald Hunsberger (NY: University of Rochester Press, 1994).

${ }^{6}$ Frank Battisti, William Berz, and Russ Girsberger, Sourcebook for Wind Band and Instrumental Music (Delray Beach, FL: Meredith Music Publications, 2014).
} 


\section{Defining the Scope of this Study}

The purpose of this document was to list all works originally composed for concert band that includes organ within the instrumentation. As part of this study, works that are considered originally composed for the concert band were subject to a modern instrumentation using the minimum ensemble requirements of at least one part for the all following:

$\begin{array}{ll}\text { Flute } & \text { Horn } \\ \text { Oboe } & \text { Trumpet } \\ \text { Bassoon } & \text { Trombone } \\ \text { Bb Clarinet } & \begin{array}{l}\text { Euphonium (Baritone) } \\ \text { Bb Bass Clarinet }\end{array} \\ & \text { Tuba/Basses } \\ \text { Eb Alto Saxophone } & \text { Timpani } \\ \text { Bb Tenor Saxophone } & \text { Percussion } \\ \text { Eb Baritone Saxophone } & \text { Organ (optional) }\end{array}$

Works with any of these instruments omitted were not included. Works that were described as Wind Ensemble or Wind Orchestra but contained at least one player per part on the above minimum requirements were included. In some instances, works for wind orchestra (or the wind section of the orchestra) that omit saxophone and euphonium, were not included but are mentioned in a later section. Some works that were included contain well beyond this instrumentation and include many different color instruments, such as the Alto Flute, English Horn, Eb Contralto Clarinet, Bb Contrabass Clarinet, Contrabassoon, Bass Saxophone, Trumpet in C, Horn in Eb, among others. Harp, Piano, Synthesizer, Celesta and a myriad of percussion instruments are also found within this listing. Any auxiliary forces such as offstage or antiphonal brass ensembles, vocal soloists, or choruses of any kind are also included as long as the minimum requirement for the concert band with inclusion of organ is met. The use of strings 
within the ensemble, besides the occasional string bass in conjunction with (not instead of) tuba and one instance of violin solo, were omitted from the study.

Transcriptions of works for other mediums were not included in this study except in the case where the original composer had transcribed his/her own work for concert band. For example, Michael Daugherty’s "Niagara Falls," was originally written for orchestra and transcribed for concert band by the composer. Arrangements of specific themes, such as Christmas carols or hymn tunes were included as long as they were original works for band and were not titled as an arrangement of a preexisting work. Compositions that came very close to meeting the minimum requirements but fell short have been included in a section following the annotated listing of works in this document.

A secondary part of this research study was to survey composers as to their thoughts on the inclusion of organ within the concert band setting and how they viewed omission or substitution of the organ parts within their works. This survey is, of course, limited to living composers identified in the preliminary research as to having included organ within one of their works for concert band.

\section{Procedures for Identifying Works}

Publishers of concert band works were identified using many different sources. An internet search for "concert band music" resulted in identifying a large number of the major music publishers. The Music Publishers Association of the United States of America maintains a directory of over 500 members that is accessible through their website. From this list, it had to be determined through further research, which entries were publishers of printed music versus those that were publishers of lyrics and recordings. Once a list was established, complete with contact 
information for each publisher, a request was sent to each individual company for assistance in locating works for concert band and organ within their catalog. Responses were collected for each publisher's reply and organized into three groups:

- YES, the publisher did find works that met the criteria

- NO, the publisher did not have any works that met these criteria

- UNABLE TO CONTACT, publishers could not be reached due to incorrect contact information

Online publisher catalogs were searched extensively, limiting queries by searching for organ and limiting the ensemble to concert band or wind ensemble. The Wind Repertory Project, $^{7}$ an online database for wind literature, was also used as a source for locating works because of its abilities to search through the instrumentation of each composition.

\section{Procedures for Surveying Composers}

Each living composer identified as having works for concert band and organ were electronically invited to participate in an anonymous research study. An email with an attached cover letter was sent to each composer with a description of the project, an invitation to participate, and a link to the online questionnaire. The composers were asked not to identify themselves in any way throughout the course of the questionnaire. The cover letter and questionnaire were subject to the approval of and was approved by the West Virginia University Office of Research Integrity and Compliance. The composers were asked four questions:

1. What does the inclusion of the organ within the concert band instrumentation add to the overall composition?

\footnotetext{
${ }^{7}$ Nick Pilato, "Wind Repertory Project," last edited May 2, 2019, http://www.windrep.org.
} 
2. When a conductor is choosing music for a performance and there is not an organ available (electronic or pipe), would you consider a synthesized organ sound a suitable substitution?

3. Are there situations where substitution would not be acceptable, and omission would be preferred?

4. Does omission of the organ part take away from the original work as it was intended?

The anonymous questionnaire was open for one month from the initial email contact for composers to complete the questions. Twenty-five composers were identified in the initial research to participate in this study. Of these, ten composers $(40 \%)$ responded to the survey.

\section{Description of Entry Formatting}

Each work found within the scope and delimitation of this study is listed alphabetically by title. Each title is followed by composer, date of publication, duration of the piece, number of movements (if applicable), the ensemble for which the work would be best suited, approximate grade level, and instrumentation. In order to help identify the purpose and difficulty level of the organ part, this information is also included.

For each grade level (graded 1-6) the following scale was utilized:

1 - Beginning Band

2 - Intermediate Middle School Band

3 - Advanced Middle School / High School Band

4 - High School Band / Early Collegiate Repertoire

5 - Advanced High School Band / Collegiate Band

6 - Collegiate / Professional Band 
Within each of these ratings is considered the length of the piece, the technical demands, the publishers rating and where the piece falls on state concert assessment lists (when applicable). Certainly, every group is different with some advanced-level high school bands easily able to play pieces in the grade 5 and 6 category. Conductors should be able to easily identify whether or not a piece is accessible to their individual group using this scale as a starting point for consideration.

The organ difficulty level is recorded on a scale considering a player who is familiar and experienced with the organ, registration and registration changes, and use of pedal work if needed. Again, the number of registration changes, dynamic responsibilities, length of the piece, and technical considerations were studied in each piece to determine a level rating. The rating system is as follows:

$\boldsymbol{E} \boldsymbol{a} \boldsymbol{y} \boldsymbol{y}$ - Mostly two-part writing, keyboard only, few registration changes, chorale-like Moderate - Registration changes, more technical passages, increased pedal use Advanced - Concerto, advanced technique needed, numerous registration changes

Also included for informational purposes is an organ category. Information provided in this section will help the conductor determine the organ's intended use in a piece. For example, an organ concerto would be marked part required, solo organ to let a conductor know that the part is not optional, and the performance is dependent on the organ part being covered. If a part is optional or ad lib., it will be marked here as well. Note that ad libitum, when referred to in the organ category, does not mean a part that is to be improvised, rather the Latin meaning of at one's pleasure, or when available per the wishes of the conductor. Categories used in the listings are: 
Sustain and Effect The organ is used for a special effect, sustained chords or notes.

Chorale-like The organ part is played in a hymn or chorale-like setting.

Full Ensemble The organ is played as a voice or timbre within the full ensemble.

Cross-cued in parts The organ part has been cued in other wind parts for use when an organ is not available.

Grand Finale The organ is used to add power and majesty to the ending of the composition.

Part Required The organ part plays an important role in the piece, whether solo or individual part and must be used to perform the composition.

Other notes relating to each individual piece may be notated in the organ category or the organ difficulty level as needed. 
The organ, referred to and praised as the "King of Instruments" by composers like Mozart and Machaut, was developed over many centuries to imitate the sounds of various orchestral and wind band instruments. Even with its imitative qualities, it is sometimes used as an ensemble voice within the modern concert band or as a unique solo instrument. When used in conjunction with a concert band, it can lend its voice as a magnificent show of power, fanfare, and majesty. In their book The Technique of Orchestration, composers Kent Keenan and Donald Grantham attempt to summarize the use of the organ in compositions when they write:

The organ is sometimes used in orchestral scores to supply added volume (generally at climactic points), liturgical atmosphere, or simply its own majestic tone quality. Occasionally the pedals alone, especially with the 16-foot or 32-foot stops, are used to double the lower orchestral instrumentations for an extra-dark, ponderous effect. Many timbres and textures are available through the stops. ${ }^{8}$

There are many areas that they address in this statement that will be discussed throughout many composers' responses in the following section. Interestingly, the statement above only refers to orchestral scores and doubling orchestral instruments, however, the idea of suppling certain textures and timbres that only the organ can provide is still sound. These textures blend magnificently with the sounds within the concert band just as easily and effectively.

Many times, because of the lack of availability, the organ is omitted from a performance as non-essential to the overall effectiveness of the piece. It was, however, the composer's intent to have the organ's voice sounding at a particular time in the music. Composers who use the organ as a voice within the ensemble must have reason for its inclusion. The composer

\footnotetext{
${ }^{8}$ Donald Grantham and Kent Kennan, The Technique of Orchestration, $5^{\text {th }}$ ed. (New Jersey: Prentice Hall, Inc., 1997), p. 150.
} 
questionnaire was designed to gain an insight into why composers use the organ within the concert band setting and what their feelings are when it comes to omission or substitution.

Question 1: What does the inclusion of the organ within the concert band instrumentation add to the overall composition?

A number of descriptors were given in answer to this question. Words such as added color, texture, power, majesty, impact, and grandeur were all adjectives to describe what effect the organ can have during the performance of a piece. The amount of depth that the pedals add when using $16^{\prime}$ ' or 32' stops was mentioned in more than one response as well as the "colors" of the upper stops such as the 2' stops or the mixtures that are unique to the organ. The organ is naturally set up to blend well with the wind ensemble from top to bottom, but there are times when the organ can be "felt more than heard" as an additional texture to the ensemble. One composer spoke of the ability of the organ to "shake a building" to help the audience physically feel the music versus times when it can also add "sweet, quiet moments with its string/celeste stops that produce a unique, necessarily aged, and captivating sound only the organ is capable of." The use of organ within a concert band was also described as "adding an extra choir" to the ensemble. The ability to bounce back and forth between woodwind choir, brass choir, and the organ adds textural depth to pieces composed for this combination.

Question 2: When a conductor is choosing music for a performance and there is not an organ available (electronic or pipe), would you consider a synthesized organ sound a suitable substitution?

The responses to this question all stemmed around one global response - the sound quality of the substitute for the organ. Although most of the responses did say yes, a synthesized organ sound would be acceptable, many included a statement such as if the sound quality was 
acceptable and suitable amplification was available. The responding composers agreed that keyboards typically do not have the correct sound needed for what they had imagined the organ part fulfilling. One composer described the artificial keyboard sound as having a "limited EQ range, resulting in highly tinny sounds that do not remotely replace the acoustic organ sound." Combined with the fact that a typical keyboard will only have one organ sound replicating full organ, it is possible to not actually meet the needs of the organ part. Another response addressed the player more than the sound of the synthesized organ. The organ part is written with a certain organ quality in mind, meaning, articulation, sustain, and often means of changing between notes. As one response said, "it takes a pianist who can think and voice the part like an organ" in order for it to be effective as intended. Although the synthesized sounds are improving, one composer did mention that if the venue did not have an organ, there is a "rise of electric organs available for purchase and rent" and it may be worth considering these instruments when planning pieces that call for organ. As mentioned earlier, it would not only depend on the electronic instrument itself, but a high-quality sound system that could match the high and low frequencies of the organ in order to make it effective. Simply using a guitar amplifier to a keyboard will not give the impression that there is an organ playing with a large ensemble.

Question 3: Are there situations where substitution would not be acceptable, and omission would be preferred?

This question stemmed more of a polemic debate than the others with half answering yes and half no, but most with extra explanation. Somewhat related to question 2, remarks about the quality of the instrument were the deciding factor. If there is a quality substitute instrument, then the part should certainly be played on that instrument. One composer went so far to say that, speaking specifically of his/her compositions, the works "should be performed with organ or a 
reasonable substitute, or not performed at all." This was reiterated in another comment where the organ was intended to be used for its soloist qualities and plays a "vital" role in the work. In this case, the composer stated that, "neither keyboard nor omission would be acceptable" for this work. Other responses referred to the purpose of the organ to the ensemble. If the organ is used to "beef up the finale" in a piece, then omission would be preferable as to using a keyboard substitute that was of inadequate quality. There are such cases where organ has important solo sections where a substitute should be used if the parts were not cross-cued in other instruments. However, one composer responded based on the intent to include organ within the instrumentation stating, "if I write for organ, I want to hear it!"

Question 4: Does omission of the organ part take away from the original work as it was intended?

Once again, the idea of the quality of sound is expressed in answer to this question. In a sense that a poor sounding organ substitute would diminish the effect of the work, omission is preferred. Admitting that, yes it does take away from the original intent, some agree that a performance with a responsibly omitted $a d$ lib or optional organ part would be preferred over non-performance of the piece. In the case where the organ is solo or concerto-like within a piece, omission completely changes the work as it was intended, and responsible decisions should be made as to the appropriateness for a performance. One composer related the omission of the organ to omission of other instruments called for in the score, stating specifically that omission of the organ part affects the intent of the piece "in the same way that omission of a double bass takes away from the composer's original intent." If there was intent to include organ in the score, it was for a reason. Whether that reason be for a grand finale in which the organ mixtures and pedal stops add texture to the ensemble that is "both felt and heard," or whether the soloistic 
sections were written for only a sound the organ can produce with its softer stops, the intent changes when the instrument is not present. While some parts are marked optional or ad lib., the intent of adding the organ creates something special within the piece that should be carefully contemplated before omission is considered.

One advantage that conductors now have is the ability to quickly contact composers with their questions. It became apparent through this study that the creators of these compositions welcome questions regarding their works and would be glad to assist in making these types of decisions. 


\section{ANNOTATIONS OF WORKS AVAILABLE FOR CONCERT BAND AND ORGAN}

\section{A Child's Garden of Dreams}

David Maslanka

$\begin{aligned} \text { Publisher: } & \text { Carl Fischer } \\ \text { Date: } & 1981 \\ \text { Duration: } & 34: 00 \\ \text { Movements: } & 5 \\ \text { Ensemble: } & \text { College / Professional } \\ \text { Grade: } & 6\end{aligned}$

Instrumentation: Piccolo I, II

Flute I, II, III

Oboe I, II, III

Eb Clarinet

$\mathrm{Bb}$ Clarinet I, II, III

$\mathrm{Bb}$ Bass Clarinet

$\mathrm{Bb}$ Contrabass Clarinet

Eb Alto Sax I, II

$\mathrm{Bb}$ Tenor Sax

Eb Bari Sax

Bassoon I, II, III

Horns I, II, III, IV

Trumpet I, II, III

Trombone I, II, III

Euphonium (Optional)

Tuba

Harp

Organ

Piano

Percussion I, II, III

Organ Level: $\quad$ Easy

Organ Category: Sustain and Effect 


\title{
A Christmas Carol Fantasy
}

Takahashi Hoshide

\author{
Publisher: De Haske Publications \\ Date: 1992 \\ Duration: $\quad 8: 00$ \\ Ensemble: High School / College \\ Grade: 5 \\ Instrumentation: Piccolo \\ Flute I, II, III \\ Oboe \\ Bassoon \\ Eb Clarinet \\ Bb Clarinet I, II, III \\ Bb Bass Clarinet \\ $\mathrm{Bb}$ Contrabass Clarinet \\ Eb Alto Sax I, II \\ $\mathrm{Bb}$ Tenor Sax \\ Eb Bari Sax \\ Horns I, II, III, IV \\ Trumpet I, II, III \\ Trombone I, II \\ Bass Trombone \\ Euphonium \\ Tuba \\ String Bass \\ Electric \& Folk Guitar (Optional) \\ Organ (Optional) \\ Drums, Timpani, Glockenspiel, Vibraphone, Xylophone, \\ Chimes, Tambourine, Triangle, Sleigh Bells, Sus. Cymbal
}

Organ Level: $\quad$ Easy

Organ Category: Optional, Chorale and Full Ensemble 


\section{Akedah}

Jesse Ayers

*with Narrator

$\begin{aligned} \text { Publisher: } & \text { Jesse Ayers Music } \\ \text { Date: } & 2013 \\ \text { Duration: } & 13.00 \\ \text { Ensemble: } & \text { High School / College } \\ \text { Grade: } & 4\end{aligned}$

Instrumentation: Flute I, II

Oboe

Bb Clarinet I, II, III

$\mathrm{Bb}$ Bass Clarinet

Eb Alto Sax I, II

$\mathrm{Bb}$ Tenor Sax

Eb Bari Sax

Bassoon

Horns I, II, III, IV

Trumpet I, II, III

Trombone I, II

Bass Trombone

Euphonium

Tuba

Organ

Piano

Percussion I, II, III, IV, V, VI

Timpani

Organ Level: $\quad$ Easy, Pedal-point and Chorale-like

Organ Category: Optional; Cross-cued in parts 


\title{
Alleluia! Laudamus Te
}

Alfred Reed

\author{
Publisher: Hal Leonard \\ Date: 1973 \\ Duration: 6:00 \\ Ensemble: High School / College \\ Grade: 5 \\ Instrumentation: Piccolo \\ Flute I, II \\ Oboe I, II \\ English Horn \\ Eb Clarinet \\ Bb Clarinet I, II, III \\ Eb Clarinet \\ Bb Bass Clarinet \\ $\mathrm{Bb}$ Contrabass Clarinet \\ Eb Alto Sax I, II \\ Bb Tenor Sax \\ Eb Bari Sax \\ Bassoon I, II \\ Horns I, II, III, IV \\ Trumpet I, II, III \\ Cornet I, II \\ Trombone I, II, III \\ Euphonium \\ Tuba \\ String Bass \\ Organ (optional) \\ Timpani \\ Percussion: Vibraphone, Xylophone, Cymbals, Snare Drum, \\ Bass Drum
}

Organ Level: $\quad$ Easy, Chorale-like

Organ Category: $\quad$ Optional, Doubles Wind Parts, Grand Finale, Processional 


\title{
Angels in the Architecture
}

Frank Ticheli

\author{
Publisher: Manhattan Beach Music \\ Date: 2009 \\ Duration: $\quad 14.00$ \\ Ensemble: College / Professional \\ Grade: 5 \\ Instrumentation: Piccolo \\ Flute I, II \\ Oboe I, II \\ English Horn \\ Bb Clarinet I, II, III, IV \\ $\mathrm{Bb}$ Bass Clarinet \\ $\mathrm{Bb}$ Contrabass Clarinet \\ Eb Alto Sax I, II \\ $\mathrm{Bb}$ Tenor Sax \\ Eb Bari Sax \\ Bassoon I, II \\ Horns I, II, III, IV \\ Trumpet I, II, III, IV \\ Trombone I, II, III \\ Euphonium \\ Tuba \\ String Bass \\ Organ \\ Celesta \\ * Soprano Soloist \\ At least 6 Percussionists: Timpani, Tuned Whirlies, Marimba, \\ Tom Toms (3), Snare Drum, Vibraphone, Suspended Cymbals, \\ Chinese cymbals (2), Crystal Wine Glasses (4), Xylophone, \\ Glockenspiel, Triangle (2), Bass Drum, Temple Blocks (4), \\ Tam Tam, Slapstick, Pedal Bass Drum, Crash Cymbals, Ratchet \\ Vibraslap
}

Organ Level: $\quad$ Easy

Organ Category: Optional, Large Chorale Section 


\title{
Archangel
}

Steve Mahpar

\author{
Publisher: MopsMusic \\ Date: 2011 \\ Duration: $\quad 12.00$ \\ Movements: 6 \\ Ensemble: College / Professional \\ Grade: 6 \\ Instrumentation: Piccolo \\ Flute I, II \\ Oboe I, II \\ Eb Clarinet \\ Bb Clarinet I, II, III \\ $\mathrm{Bb}$ Bass Clarinet \\ Eb Alto Sax I, II \\ Bb Tenor Sax \\ Eb Bari Sax \\ Bassoon I, II \\ Horns I, II, III, IV \\ Trumpet I, II, III \\ Trombone I, II, III \\ Euphonium \\ Tuba \\ Harp \\ Keyboard (Organ/Piano) \\ Percussion (6 players) \\ Tam-Tam, Suspended Cymbal, Chains, Crash Cymbals, \\ Bass Drum, Glockenspiel, Brake Drum, Crotales, Chimes \\ Timpani
}

Organ Level: $\quad$ Moderate, Shares part with Piano Organ Category: Optional, but preferred 


\section{Ares}

Amanda McCullough

$\begin{aligned} \text { Publisher: } & \text { Amanda McCullough } \\ \text { Date: } & \text { Unknown } \\ \text { Duration: } & 9: 00 \\ \text { Ensemble: } & \text { High School / College } \\ \text { Grade: } & 5\end{aligned}$

Instrumentation: Piccolo I, II

Flute I, II

Oboe I, II

Bb Clarinet I, II, III, IV

Bb Bass Clarinet

Eb Contralto Clarinet

$\mathrm{Bb}$ Contrabass Clarinet

Eb Alto Sax I, II

$\mathrm{Bb}$ Tenor Sax

Eb Bari Sax

Bassoon I, II

Contrabassoon

Horns I, II, III, IV

Trumpet I, II, III, IV

Trombone I, II

Bass Trombone

Euphonium

Tuba

String Bass

Organ (optional)

Timpani

Percussion: Snare Drum, Bass Drum, Suspended Cymbal

Tam-Tam

Organ Level: Moderate, long sustains, technical interjections

Organ Category: Optional, but recommended 
Bell-Tones Ring

Kenneth Amis

\author{
Publisher: Amis Musical Circle \\ Date: 1999 \\ Duration: 5:00 \\ Ensemble: High School / College \\ Grade: 5 \\ Instrumentation: Piccolo \\ Flute I, II \\ Oboe I, II \\ English Horn \\ Bb Clarinet I, II, III \\ $\mathrm{Bb}$ Bass Clarinet \\ Eb Alto Sax I, II \\ Bb Tenor Sax \\ Eb Bari Sax \\ Bassoon \\ Horns I, II, III, IV \\ Cornet I, II, III \\ Trumpet I, II \\ Trombone I, II, III \\ Euphonium \\ Tuba \\ String Bass \\ Organ (optional) \\ * $\quad$ SATB Chorus (optional) \\ Percussion I, II, III
}

Organ Level: $\quad$ Moderate, Chorale-like

Organ Category: $\quad$ Optional, Grand Finale, Hymn tune 


\title{
Bells for Stokowski
}

Michael Daugherty

\author{
Publisher: Peer Music Ltd. \\ Date: 2001 \\ Duration: $14: 00$ \\ Ensemble: College / Professional \\ Grade: 6 \\ Instrumentation: Piccolo \\ Flute I, II, III, IV \\ Oboe I, II \\ English Horn \\ Bb Clarinet I, II, III, IV \\ $\mathrm{Bb}$ Bass Clarinet \\ $\mathrm{Bb}$ Contrabass Clarinet \\ Bb Soprano Sax \\ Eb Alto Sax \\ $\mathrm{Bb}$ Tenor Sax \\ Eb Bari Sax \\ Bassoon I, II \\ Contrabassoon \\ Horns I, II, III, IV \\ Trumpet I, II, III, IV \\ Trombone I, II \\ Bass Trombone \\ Euphonium \\ Tuba \\ String Bass (2) \\ Guitar (optional) \\ Harp (2) \\ Pipe Organ \\ Percussion (5 players needed): Timpani, Bass Drum, Bell Plate \\ (2), Chimes, Crash Cymbals (med \& large), Crotales (2), \\ Glockenspiel, Marimba, Mark Tree, Sleigh Bells, Tam-Tam (2), \\ Vibraphone
}

Organ Level: Advanced

Organ Category: Part Required, Solo Organ 


\section{Canterbury Chorale}

Jan Van der Roost

$\begin{aligned} \text { Publisher: } & \text { De Haske Publications } \\ \text { Date: } & 1991 \\ \text { Duration: } & 6: 00 \\ \text { Ensemble: } & \text { High School / College } \\ \text { Grade: } & 4\end{aligned}$

Instrumentation: Piccolo I, II

Flute I, II

Oboe I, II

Alto Oboe (English Horn)

$\mathrm{Eb}$ Clarinet

Bb Clarinet I, II, III

Eb Alto Clarinet

Bb Bass Clarinet

$\mathrm{Bb}$ Contrabass Clarinet

Bb Soprano Sax (ad lib. Clarinet I)

Eb Alto Sax I, II

$\mathrm{Bb}$ Tenor Sax

Eb Bari Sax

Bassoon I, II, III

Horns I, II, III

Trumpet/Cornet I, II, III

Trombone I, II, III

Euphonium (Optional)

Basses

String Bass

Organ (Optional, ad lib)

Timpani, Bells, Cymbals

Organ Level: $\quad$ Easy, Chorale-like

Organ Category: Organ ad lib. 


\title{
Canticle: All Creatures of Our God and King
}

Claude T. Smith

\author{
Publisher: Wingert-Jones Music, Inc \\ Date: 1984 \\ Duration: 6:00 \\ Ensemble: High School / College \\ Grade: 5 \\ Instrumentation: Piccolo \\ Flute I, II \\ Oboe I, II \\ Eb Clarinet \\ Bb Clarinet I, II, III \\ Eb Alto Clarinet \\ Bb Bass Clarinet \\ $\mathrm{Bb}$ Contrabass Clarinet \\ Eb Alto Sax I, II \\ Bb Tenor Sax \\ Eb Bari Sax \\ Bassoon I, II \\ Horns I, II, III, IV \\ Trumpet I, II, III \\ Trombone I, II \\ Bass Trombone \\ Euphonium \\ Tuba \\ String Bass \\ Organ (optional) \\ Timpani \\ Percussion: Bells, Xylophone, Chimes, Snare Drum, Suspended \\ Cymbal, Gong, Bass Drum, Crash Cymbals \\ Organ Level: $\quad$ Easy, Chorale-like \\ Organ Category: Optional, Grand Finale, Hymn tune
}




\title{
Captain Majesty: A Celebration Hymn for Symphonic Band
}

Timothy Rhea

\author{
Publisher: TRN Publishers \\ Date: 1998 \\ Duration: 7:00 \\ Ensemble: High School / College \\ Grade: $\quad 4$ \\ Instrumentation: Piccolo \\ Flute I, II \\ Oboe I, II \\ Bb Clarinet I, II, III \\ $\mathrm{Bb}$ Bass Clarinet \\ Eb Alto Sax I, II \\ $\mathrm{Bb}$ Tenor Sax \\ Eb Bari Sax \\ Bassoon I, II \\ Horns I, II, III, IV \\ Trumpet I, II, III \\ Trombone I, II, III \\ Euphonium \\ Tuba \\ Organ \\ Timpani \\ Bells, Chimes, Temple Blocks, Vibraphone, Gong, Triangle, \\ Cymbals, Tambourine, Wind Chimes, Snare Drum, Bass Drum \\ * Optional Antiphonal Brass
}

Organ Level: $\quad$ Easy

Organ Category: $\quad$ Optional, Fanfare, Grand Finale 


\title{
Celebration Fanfare - An Overture for Symphonic Band
}

Steven Reineke

\author{
Publisher: C.L. Barnhouse \\ Date: 2008 \\ Duration: $\quad 4: 30$ \\ Ensemble: High School / College \\ Grade: $\quad 4$ \\ Instrumentation: Piccolo \\ Flute I, II \\ Oboe \\ Bb Clarinet I, II, III \\ $\mathrm{Bb}$ Bass Clarinet \\ Eb Alto Sax I, II \\ Bb Tenor Sax \\ Eb Bari Sax \\ Bassoon I, II \\ Horns I, II \\ Trumpet I, II, III \\ Trombone I, II, III \\ Euphonium \\ Tuba \\ String Bass (optional) \\ Harp (optional) \\ Organ/Piano (optional) \\ Timpani \\ Percussion: Chimes, Glockenspiel, Tam-Tam, Crash Cymbals, \\ Mark Tree, Snare Drum, Bass Drum, Vibes, \\ Xylophone, Triangle
}

Organ Level: Moderate

Organ Category: Optional, shared part with piano, one player 


\section{Celebration Fanfare for Organ and Concert Band}

Satoshi Yagisawa

$\begin{aligned} \text { Publisher: } & \text { De Haske Publications } \\ \text { Date: } & 2013 \\ \text { Duration: } & 5: 00 \\ \text { Ensemble: } & \text { Middle School / High School } \\ \text { Grade: } & 3 \\ \text { Instrumentation: } & \text { Piccolo } \\ & \text { Flute I, II } \\ & \text { Oboe } \\ & \text { Bb Clarinet I, II, III } \\ & \text { Bb Bass Clarinet } \\ & \text { Eb Alto Sax I, II } \\ & \text { Bb Tenor Sax } \\ & \text { Eb Bari Sax } \\ & \text { Bassoon } \\ & \text { Horns I, II, III, IV } \\ & \text { Trumpet I, II, III } \\ & \text { Trombone I, II, III } \\ & \text { Euphonium } \\ & \text { Tuba } \\ & \text { String Bass } \\ & \text { Organ } \\ & \text { Timpani } \\ & \text { Percussion I, II, III, IV, V } \\ & \\ & \text { Moderate - Advanced } \\ & \text { Chordal Fanfare, Cadenza Solo } \\ & \\ & \\ & \\ & \\ & \\ & \\ & \\ & \\ & \\ & \\ & \\ & \\ & \\ & \\ & \end{aligned}$




\title{
Celebration Overture for Wind Ensemble
}

James Stephenson

\author{
Publisher: Stephenson Music \\ Date: 2018 \\ Duration: 10:00 \\ Ensemble: High School / College \\ Grade: 5 \\ Instrumentation: Piccolo \\ Flute I, II \\ Oboe I, II \\ $\mathrm{Bb}$ Clarinet I, II \\ Bb Soprano Sax \\ Eb Alto Sax \\ Bb Tenor Sax \\ Eb Bari Sax \\ Bassoon I, II \\ Horns I, II \\ Trumpet I, II (in C) \\ Trombone I, II \\ Euphonium \\ Tuba \\ String Bass \\ Organ \\ Piano \\ Timpani \\ Percussion: Vibes, Glockenspiel, Triangle, Wood Block, \\ Sand Block, Suspended Cymbal, Bass Drum, \\ Snare Drum
}

Organ Level: $\quad$ Easy

Organ Category: Solo Organ, Part Required 


\title{
Cheers! A Celebration March
}

\author{
Publisher: G. Schirmer, Inc. / Hal Leonard \\ Date: 1979 \\ Duration: 5:00 \\ Ensemble: High School / College \\ Grade: $\quad 4$ \\ Instrumentation: Piccolo \\ Flute I, II \\ Oboe I, II \\ English Horn (optional) \\ Eb Clarinet \\ Bb Clarinet I, II, III \\ Eb Alto Clarinet \\ Bb Bass Clarinet \\ Bb Contrabass Clarinet \\ Eb Alto Sax I, II \\ $\mathrm{Bb}$ Tenor Sax \\ Eb Bari Sax \\ Bassoon \\ Horns I, II, III, IV \\ Trumpet I, II, III, IV \\ Trombone I, II, III, IV \\ Euphonium \\ Tuba \\ String Bass (optional) \\ Organ (optional) \\ Timpani \\ Percussion: Tambourine, Cymbals, Bass Drum, Tenor Drum, \\ Snare Drum, Suspended Cymbal, Castanets, Bongos \\ Triangle, Tam-Tam, Chimes, Marimba, Xylophone, \\ Vibraphone
}

Organ Level: $\quad$ Easy

Organ Category: Optional 


\title{
Christmas Celebration
}

Alfred Reed

*for concert band, brass choir, and SATB chorus

\author{
Publisher: Hal Leonard \\ Date: 1987 \\ Duration: 17:00 \\ Ensemble: High School / College \\ Grade: $\quad 4$ \\ Instrumentation: Piccolo \\ Flute I, II, III \\ Oboe I, II \\ English Horn \\ Eb Clarinet \\ Bb Clarinet I, II, III \\ Eb Alto Clarinet \\ $\mathrm{Bb}$ Bass Clarinet \\ $\mathrm{Bb}$ Contrabass Clarinet \\ Eb Alto Sax I, II \\ $\mathrm{Bb}$ Tenor Sax \\ Eb Bari Sax \\ Bassoon I, II \\ Horns I, II, III, IV \\ Brass Choir \\ Trumpet I, II, III \\ Trumpet I, II, III \\ Cornet I, II \\ Trombone I, II, III \\ Trombone I, II, III \\ Euphonium \\ Tuba \\ String Bass \\ Harp/Piano \\ Organ \\ Timpani \\ Percussion: Snare Drum, Bass Drum, Pair of Cymbals, Triangle, \\ Sleigh Bells, Bells, Chimes, Xylophone \\ * $\quad$ SATB Chorus \\ Organ Level: $\quad$ Easy \\ Organ Category: $\quad$ Grand Finale, Full Organ
}




\section{Circus Polka}

$\begin{aligned} \text { Publisher: } & \text { Schott Music International } \\ \text { Date: } & 1942 \\ \text { Duration: } & 4: 00 \\ \text { Ensemble: } & \text { College / Professional } \\ \text { Grade: } & 6\end{aligned}$

Instrumentation: Flute I, II

Oboe

Bb Clarinet I, II, III (Solo I, II)

Eb Alto Clarinet

$\mathrm{Bb}$ Bass Clarinet

Eb Alto Sax I, II

$\mathrm{Bb}$ Tenor Sax

Eb Bari Sax

Bassoon

Horns I, II, III

Solo Cornet I, II

Cornet I, II, III

Trombone I, II, III, IV

Euphonium I, II

Tuba I, II

Hammond Organ

Percussion: Xylophone, Snare Drum, Cymbals, Bass Drum

Organ Level: Moderate

Organ Category: Optional, Calls specifically for Hammond Organ

* An edition for much smaller wind section is also available. 


\title{
Cloud of Witnesses
}

D.J. Sparr

\author{
Publisher: Bill Holab Music \\ Date: 2015 \\ Duration: 9:00 \\ Ensemble: College / Professional \\ Grade: 5 \\ Instrumentation: 1 Piccolos \\ (Exact Instrumentation) 5 Flutes \\ 2 Oboes \\ 1 English Horn \\ 6 Clarinets in $\mathrm{Bb}$ \\ 1 Bass Clarinet \\ 2 Alto Saxophones \\ 1 Tenor Saxophone \\ 1 Baritone Saxophone \\ 2 Bassoons \\ 1 Contrabassoon \\ 4 Horns in $\mathrm{F}$ \\ 4 Trumpets in $\mathrm{Bb}$ \\ $2 \mathrm{Bb}$ Flugelhorns \\ 2 Tenor Trombones \\ 1 Bass Trombone \\ 1 Euphonium \\ 2 Tubas \\ String Bass \\ Timpani \\ Percussion: Vibraphone, Tuned Metal, Glockenspiel, \\ Almglocken, Tubular Bells \\ Harp \\ Piano \\ Organ (or synthesized organ sound)
}

Organ Level: $\quad$ Easy, Single Note Sustains throughout

Organ Category: Synthesizer (with organ sound) or Organ 


\section{Concerto for Band and Organ}

Raynor Brown

\begin{tabular}{|c|c|c|}
\hline Publisher: & Western International Music & \\
\hline & 1960 & Movements \\
\hline Duration: & ca. $32: 00$ & I. Allegro \\
\hline Movements: & 4 & II. Andante \\
\hline Ensemble: & College / Professional & III. Scherzo \\
\hline Grade: & 5 & IV. Fugue \\
\hline Instrumentation: & Piccolo & \\
\hline & Flute I, II & \\
\hline & Oboe I, II & \\
\hline & Eb Clarinet & \\
\hline & Bb Clarinet I, II, III & \\
\hline & Eb Alto Clarinet & \\
\hline & $\mathrm{Bb}$ Bass Clarinet & \\
\hline & Eb Alto Sax I, II & \\
\hline & $\mathrm{Bb}$ Tenor Sax & \\
\hline & Eb Bari Sax & \\
\hline & Bassoon I, II, III & \\
\hline & Horns I, II, III, IV & \\
\hline & Trumpet I, II, III & \\
\hline & Trombone I, II, III & \\
\hline & Euphonium I, II & \\
\hline & Tuba & \\
\hline & String Bass & \\
\hline & Harp & \\
\hline & Organ & \\
\hline & Timpani & \\
\hline & Percussion I, II, III & \\
\hline Organ Level: & Advanced & \\
\hline Organ Category: & Concerto, Organ Solo & \\
\hline
\end{tabular}




\section{Crown Him with Many Crowns}

James Swearingen

$\begin{aligned} \text { Publisher: } & \text { C.L. Barnhouse } \\ \text { Date: } & 1999 \\ \text { Duration: } & 3: 00 \\ \text { Ensemble: } & \text { Middle School / High School } \\ \text { Grade: } & 3 \\ & \\ \text { Instrumentation: } & \text { Piccolo } \\ & \text { Flute } \\ & \text { Oboe } \\ & \text { Bb Clarinet I, II, III } \\ & \text { Bb Bass Clarinet } \\ & \text { Eb Alto Sax I, II } \\ & \text { Bb Tenor Sax } \\ & \text { Eb Bari Sax } \\ & \text { Bassoon } \\ & \text { Horns I, II } \\ & \text { Trumpet I, II, III } \\ & \text { Trombone I, II, III } \\ & \text { Euphonium } \\ & \text { Tuba } \\ & \text { String Bass } \\ & \text { Organ (optional) } \\ & \text { Timpani } \\ & \text { Percussion: Chimes, Xylophone, Snare Drum, Bass Drum, } \\ & \\ & \\ & \\ & \\ & \\ & \\ & \\ & \end{aligned}$

Organ Level: $\quad$ Easy, Chorale-like

Organ Category: Optional, Chorale Sections 


\section{Deep Field}

Publisher: Music Sales Corporation

Date: 2015

Duration: 23:00

Ensemble: College / Professional

Grade: 6

Instrumentation: Piccolo

Flute I, II, III

Oboe I, II

English Horn

Bb Clarinet I, II, III, IV, V, VI, VII, VIII, IX

Bb Bass Clarinet I, II

$\mathrm{Bb}$ Contrabass Clarinet

Eb Alto Sax I, II

Bb Tenor Sax

Eb Bari Sax

Bassoon I, II, III (doubles contrabassoon)

Horns I, II, III, IV, V, VI

Trumpet I, II, III, IV

Trombone I, II

Bass Trombone

Euphonium I, II

Tuba I, II

String Bass

Harp

Organ

Piano

SATB Chorus

Timpani

Percussion: Crotales (2), Vibraphone (2), Marimba (2),

Suspended Cymbal, Tam-Tam, Snare Drum (2),

Bass Drum (2)

Organ Level: Moderate

Organ Category: Optional 


\title{
Echoes of San Marco
}

Johan de Meij

\author{
Publisher: Amstel Publications \\ Date: 2016 \\ Duration: 10:00 \\ Ensemble: High School / College \\ Grade: $\quad 4$ \\ Instrumentation: Flute I / Piccolo \\ Flute II \\ Alto Flute in $\mathrm{G}$ \\ Bass Flute in $\mathrm{C}$ \\ Oboe I, II \\ English Horn \\ Eb Clarinet \\ Bb Clarinet I, II, III \\ Bb Bass Clarinet \\ $\mathrm{Bb}$ Contrabass Clarinet \\ Eb Alto Sax I, II \\ $\mathrm{Bb}$ Tenor Sax \\ Eb Bari Sax \\ Bassoon I, II \\ Contrabassoon \\ Horns I, II, III, IV \\ Trumpet I, II, III, IV \\ Trombone I, II, III \\ Bass Trombone \\ Euphonium \\ Tuba \\ String Bass \\ Harp \\ Organ \\ Timpani \\ Percussion: Chimes (2), Bass Drum, Snare Drum, Sus. Cymbal, \\ Crash Cymbals
}

Organ Level: Moderate

Organ Category: Required for Performance 


\title{
Fanfare and Grand March
}

Timothy Mahr

\author{
Publisher: Neil A. Kjos Music Company \\ Date: $\quad 1980$ \\ Duration: 2:00 \\ Ensemble: High School / College \\ Grade: $\quad 4$ \\ Instrumentation: Piccolo \\ Flute I, II \\ Oboe \\ Eb Clarinet \\ Bb Clarinet I, II, III \\ Eb Alto Clarinet \\ $\mathrm{Bb}$ Bass Clarinet \\ $\mathrm{Bb}$ Contrabass Clarinet \\ Eb Alto Sax I, II \\ $\mathrm{Bb}$ Tenor Sax \\ Eb Bari Sax \\ Bassoon \\ Horns I, II, III, IV \\ Trumpet I, II, III, IV \\ Trombone I, II, III \\ Euphonium \\ Tuba \\ String Bass \\ Organ \\ Timpani \\ Percussion: Chimes, Crash Cymbal, Snare Drum, Bass Drum \\ Organ Level: $\quad$ Easy, Chorale-like \\ Organ Category: Optional, ad lib. WW part, Grand Finale
}


Fantasia Variations on Eternal Alleluias

Daniel Kallman

$\begin{aligned} \text { Publisher: } & \text { TRN Publishers } \\ \text { Date: } & 1990 \\ \text { Duration: } & 7: 30 \\ \text { Ensemble: } & \text { College / Professional } \\ \text { Grade: } & 5 \\ \text { Instrumentation: } & \text { Piccolo } \\ & \text { Flute I, I } \\ & \text { Oboe I, II } \\ & \text { Eb Clarinet } \\ & \text { Bb Clarinet I, II, III } \\ & \text { Eb Alto Clarinet } \\ & \text { Bb Bass Clarinet } \\ & \text { Bb Contrabass Clarinet } \\ & \text { Bb Soprano Saxophone } \\ & \text { Eb Alto Sax I, II } \\ & \text { Bb Tenor Sax } \\ & \text { Eb Bari Sax } \\ & \text { Bassoon I, II } \\ & \text { Horns I, II, III, IV } \\ & \text { Trumpet I, II, III } \\ & \text { Trombone I, II, III } \\ & \text { Euphonium } \\ & \text { Tuba } \\ & \text { String Bass } \\ & \text { Organ (optional) } \\ & \\ & \\ & \\ & \\ & \\ & \end{aligned}$

Organ Level: $\quad$ Easy, Hymn tune

Organ Category: $\quad$ Optional, Grand Finale 


\author{
Publisher: Piquant Press \\ Date: 2015 \\ Duration: 5:00 \\ Ensemble: High School / College \\ Grade: 4 \\ Instrumentation: Flute I, II \\ Oboe I, II \\ Bb Clarinet I, II, III \\ $\mathrm{Bb}$ Bass Clarinet \\ $\mathrm{Bb}$ Contrabass Clarinet \\ Eb Alto Sax I, II \\ $\mathrm{Bb}$ Tenor Sax \\ Eb Bari Sax \\ Bassoon I, II \\ Horns I, II, III, IV \\ Trumpet I, II, III \\ Trombone I, II \\ Bass Trombone \\ Euphonium \\ Tuba \\ String Bass \\ Organ \\ Timpani \\ Percussion: Chimes, Glockenspiel, Vibraphone (2)
}

Organ Level: $\quad$ Moderate

Organ Category: Optional, but preferred; cross-cued in parts 


\section{Festival Fanfare}

Phillip Andrew Brookes

$\begin{aligned} \text { Publisher: } & \text { Musikproduktion Höflich } \\ \text { Date: } & 2015 \\ \text { Duration: } & 2: 00 \\ \text { Ensemble: } & \text { High School / College } \\ \text { Grade: } & 4\end{aligned}$

Instrumentation: Flute I, II, III

Oboe

English Horn

Eb Clarinet

Bb Clarinet I, II, III

Bb Bass Clarinet

Eb Alto Sax I, II

$\mathrm{Bb}$ Tenor Sax

Eb Bari Sax

Bassoon

Contrabassoon

Horns I, II, III, IV

Trumpet I, II, III

Trombone I, II, III

Euphonium

Tuba

Organ

Timpani

Percussion

* Optional String Parts Available

Organ Level: $\quad$ Easy

Organ Category: Optional, ad lib. 


\title{
Festival Fanfare for Christmas
}

John Wasson

*Originally for Orchestra, Transcribed for Band by the composer

\author{
Publisher: Hal Leonard \\ Date: 2008 \\ Duration: 4:00 \\ Ensemble: High School / College \\ Grade: 5 \\ Instrumentation: Piccolo \\ Flute I, II \\ Oboe I, II \\ Bb Clarinet I, II, III \\ $\mathrm{Bb}$ Bass Clarinet \\ Eb Alto Sax I, II \\ $\mathrm{Bb}$ Tenor Sax \\ Eb Bari Sax \\ Bassoon I, II \\ Horns I, II, III, IV \\ Trumpet I, II, III, IV \\ Trombone I, II, III \\ Euphonium \\ Tuba \\ String Bass \\ Organ \\ Timpani \\ Percussion: Snare Drum, Bass Drum, Gong, Triangle, \\ Suspended Cymbal, Crash Cymbal, Bells, Chimes \\ Organ Level: Moderate \\ Organ Category: Plays throughout, Doubling parts
}




\section{Finest Hour!}

Stephen Melillo

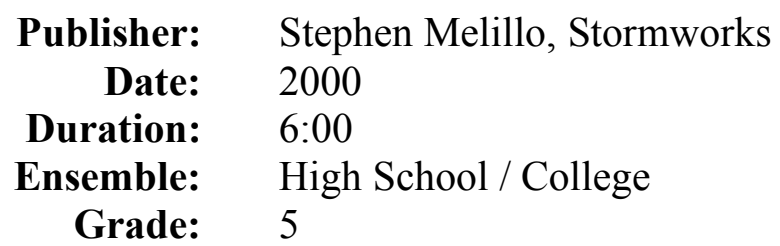

Instrumentation: Flute I, II

Oboe

Bb Clarinet I, II

$\mathrm{Bb}$ Bass Clarinet

Eb Alto Sax I, II

Bb Tenor Sax

Eb Bari Sax

Bassoon

Horns I, II, III

Trumpet I, II, III

Trombone I, II

Bass Trombone

Euphonium

Tuba

PAD Bass

Harp

Pipe Organ (synthesizer)

* $\quad$ SATB Chorus (can be on synthesizer)

Timpani

Percussion: Chimes, Orchestra Bells, Snare Drum, Bass

Drum, Crash Cymbal, Wind Chimes, Suspended

Cymbal, Large Tam-Tam

Organ Level: $\quad$ Easy, Pedal and Melodic Line

Organ Category: Synthesized sound intended, effective on organ 


\section{Gloriana}

Jay Bocook

$\begin{aligned} \text { Publisher: } & \text { Hal Leonard } \\ \text { Date: } & 2015 \\ \text { Duration: } & 4: 00 \\ \text { Ensemble: } & \text { High School / College } \\ \text { Grade: } & 5\end{aligned}$

Instrumentation: Piccolo

Flute I, II

Oboe I, II

English Horn

Bb Clarinet I, II, III

$\mathrm{Bb}$ Bass Clarinet

Eb Alto Sax I, II

Bb Tenor Sax

Eb Bari Sax

Bassoon I, II

Horns I, II, III, IV

Trumpet I, II, III

Trombone I, II, III

Euphonium

Tuba

String Bass

Organ

Percussion: Crash Cymbal, Bass Drum, Suspended Cymbal, Bells, Chimes

Organ Level: $\quad$ Easy

Organ Category: Optional 


\section{Homage}

Jan Van der Roost

$\begin{aligned} \text { Publisher: } & \text { De Haske Publications } \\ \text { Date: } & 1994 \\ \text { Duration: } & 5: 30 \\ \text { Ensemble: } & \text { High School / College } \\ \text { Grade: } & 5 \\ \text { Instrumentation: } & \text { Piccolo } \\ & \text { Flute I, II } \\ & \text { Oboe I, II } \\ & \text { English Horn } \\ & \text { Eb Clarinet } \\ & \text { Bb Clarinet I, II, III } \\ & \text { Eb Alto Clarinet } \\ & \text { Bb Bass Clarinet } \\ & \text { Bb Contrabass Clarinet } \\ & \text { Eb Alto Sax I, II } \\ & \text { Bb Tenor Sax } \\ & \text { Eb Bari Sax } \\ & \text { Bassoon I, II } \\ & \text { Horns I, II, III, IV } \\ & \text { Trumpet/Cornet I, II, III } \\ & \text { Trombone I, II } \\ & \text { Bass Trombone } \\ & \text { Euphonium I, II } \\ \text { Tuba } & \\ \text { Organ Level: } & \text { String Bass } \\ & \text { Easy, Chorale-like } \\ & \text { Od lib., Grand Finale } \\ & \\ & \text { Organ } \\ & \text { Timpani } \\ & \text { Percussion I, II, III } \\ & \\ & \\ & \\ & \end{aligned}$




\section{In Adventu Finalem}

Andrew Boss

$\begin{aligned} \text { Publisher: } & \text { Murphy Music Press } \\ \text { Date: } & 2018 \\ \text { Duration: } & 50: 00 \\ \text { Ensemble: } & \text { College / Advanced } \\ \text { Grade: } & 6\end{aligned}$

Instrumentation: Flute I, II

Oboe I, II

Bb Clarinet I, II, III

Bb Bass Clarinet

$\mathrm{Bb}$ Contrabass Clarinet

Eb Alto Sax I, II

$\mathrm{Bb}$ Tenor Sax

Eb Bari Sax

Bassoon I, II

Contrabassoon

Horns I, II, III, IV

Trumpet I, II, III, IV

Trombone I, II, III

Bass Trombone

Euphonium

Tuba

String Bass

Harp

Organ

Piano/Celesta

\section{Antiphonal Wind Quintet}

Flute, Oboe

Clarinet, Alto Sax,

Bassoon

Horn V, VI

Antiphonal Brass

Trumpet V, VI. VII, VIII

Trombone V, VI

\section{Antiphonal Percussion}

Tam-Tam, Med. Sus. Cymbal Sizzle Cymbal, Bell Tree, Chimes, Crotales, Large Sus. Cymbal, Sizzle Cymbal

Percussion I, II, III, IV, V, VI

Timpani (5), Vibraphone (2), Chimes, Bass Drum, Water Gong, Tom-Toms, Crotales (2), Triangle, Tam-Tam, Finger Cymbals, Crash Cymbal, Waterphone, Marimba, Xylophone, Bongos, Glockenspiel, Temple Blocks, Slap-Stick, Med. Suspended Cymbal, Snare Drum, Tenor Drum, Large Suspended Cymbal

Organ Level: $\quad$ Moderate

Organ Category: $\quad$ Part Required, Suggested Registrations Included 


\section{In Memorium}

David Maslanka

$\begin{aligned} \text { Publisher: } & \text { Maslanka Press } \\ \text { Date: } & 1989 \\ \text { Duration: } & 13: 00 \\ \text { Ensemble: } & \text { High School / College } \\ \text { Grade: } & 5\end{aligned}$

Instrumentation: Piccolo

Flute I, II

Oboe I, II

Eb Clarinet

Bb Clarinet I, II

Bb Bass Clarinet

$\mathrm{Bb}$ Contrabass Clarinet

Eb Alto Sax I, II

Bb Tenor Sax

Eb Bari Sax

Bassoon

Horns I, II, III, IV

Trumpet I, II, III

Trombone I, II, III

Bass Trombone

Euphonium

Tuba

String Bass

Organ

Piano

Timpani

Percussion: Xylophone, Suspended Cymbal (3), Chimes, Triangle (2), Tam-Tam, Marimba, Vibraphone, Snare Drum (2), Glockenspiel (2), Bass Drum (2), Tom-Tom, Bongo, Rin (5), Japanese Temple Gongs (4), Crash Cymbals, Anvil, Tenor Drum

Organ Level: $\quad$ Easy, Chorale-like Organ Category: Preferred, Chordal 


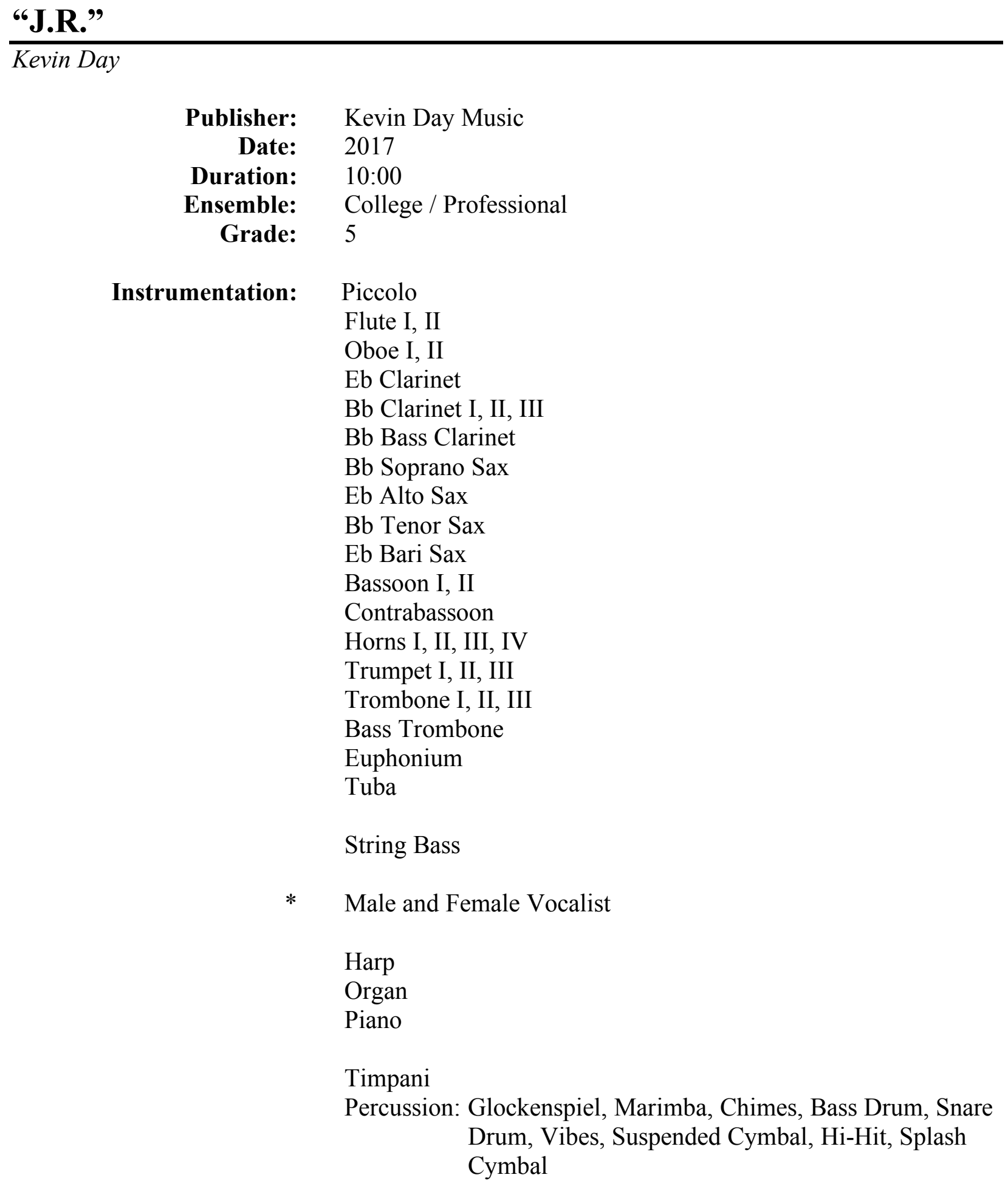

Organ Level: $\quad$ Easy, Chordal, Hymn-tune

Organ Category: Part Required, Solo Accompaniment, Grand Finale 
King Ubu

Michael Schelle

\author{
Publisher: Lauren Keiser / Hal Leonard \\ Date: 1981 \\ Duration: 18:00 \\ Movements: 3 \\ Ensemble: College / Professional \\ Grade: 6 \\ Instrumentation: Piccolo \\ Flute I, II \\ Oboe I, II \\ Eb Clarinet \\ Bb Clarinet I, II, III \\ $\mathrm{Bb}$ Bass Clarinet \\ $\mathrm{Bb}$ Contrabass Clarinet \\ Eb Alto Sax I, II \\ Bb Tenor Sax \\ Eb Bari Sax \\ Bassoon I, II \\ Horns I, II, III, IV \\ Trumpet I, II, III, IV \\ Trombone I, II, III \\ Tuba \\ Organ \\ Timpani \\ Percussion I, II, III, IV \\ Movements \\ I. Pines of Ubu \\ II. Ubu in Love \\ III. Ubu in Chains
}

\footnotetext{
* Solo Violin

Organ Level: Easy, Hymn-tune, Chorale

Organ Category: Optional but "highly desired!"

Hidden/Off-Stage Console
} 


\section{Lauda Anima}

Stephen Bulla

$\begin{aligned} \text { Publisher: } & \text { Hal Leonard } \\ \text { Date: } & 2004 \\ \text { Duration: } & 3: 30 \\ \text { Ensemble: } & \text { Middle School / High School } \\ \text { Grade: } & 3\end{aligned}$

Instrumentation: Flute/Piccolo

Oboe

Bb Clarinet I, II, III

Eb Alto Clarinet

$\mathrm{Bb}$ Bass Clarinet

Eb Alto Sax I, II

Bb Tenor Sax

Eb Bari Sax

Bassoon

Horns I, II

Trumpet I, II, III

Trombone I, II, III

Euphonium

Tuba

String Bass

Organ (optional)

Timpani

Percussion: Vibraphone, Chimes, Orchestra Bells, Snare Drum, Bass Drum, Triangle, Crash Cymbal, Suspended Cymbal, Tambourine

Organ Level: Easy, mostly two-part, some technique at end Organ Category: Optional, but preferred, doubles other parts 


\title{
Lead On, O King Eternal
}

James Swearingen

\author{
Publisher: C.L. Barnhouse \\ Date: $\quad 2000$ \\ Duration: 3:00 \\ Ensemble: Middle School / High School \\ Grade: 3 \\ Instrumentation: Flute/Piccolo \\ Oboe \\ Bb Clarinet I, II, III \\ $\mathrm{Bb}$ Bass Clarinet \\ Eb Alto Sax I, II \\ $\mathrm{Bb}$ Tenor Sax \\ Eb Bari Sax \\ Bassoon \\ Horns I, II \\ Trumpet I, II, III \\ Antiphonal Brass \\ Trombone I, II, III \\ Trumpet I, II, III \\ Euphonium \\ Tuba \\ Trombone I, II, III \\ Organ (optional) \\ Timpani \\ Percussion: Bells, Chimes, Snare Drum, Bass Drum, Suspended \\ Cymbal, Crash Cymbal, Mark Tree \\ * $\quad$ SATB Chorus (optional) \\ Organ Level: $\quad$ Easy, Chorale-like \\ Organ Category: Optional
}




\author{
Publisher: Boosey \& Hawkes \\ Date: 1933 \\ Duration: 11:00 \\ Ensemble: High School / College \\ Grade: 5 \\ Instrumentation: Piccolo \\ Flute I, II \\ Oboe \\ Eb Clarinet \\ Solo Bb Clarinet \\ Bb Clarinet I, II, III \\ Eb Alto Clarinet \\ $\mathrm{Bb}$ Bass Clarinet \\ $\mathrm{Bb}$ Contrabass Clarinet \\ Eb Alto Sax \\ Bb Tenor Sax \\ Eb Bari Sax \\ Bb Bass Saxophone \\ Bassoon I, II \\ Horns I, II, III, IV \\ Cornet I, II, III \\ Trumpet in $\mathrm{Bb}$ \\ Flugelhorn I, II \\ Trombone I, II, III \\ Euphonium \\ Tuba \\ String Bass \\ Organ \\ Timpani \\ Drums
}

Organ Level: $\quad$ Easy, Chorale-like

Organ Category: $\quad$ Optional, Grand Finale 

Publisher: Maslanka Press
Date: 1996 / 2005 revision
Duration: 1:35:00
Ensemble: College / Professional
Grade: $\quad 6+$

Instrumentation: Flute I, II / Piccolo

Oboe I, II / English Horn

Bb Clarinet I, II

$\mathrm{Bb}$ Bass Clarinet

Eb Contrabass Clarinet

Eb Alto Sax I, II / Soprano Saxophone

Bb Tenor Sax

Eb Bari Sax

Bassoon I, II / Contrabassoon

Horns I, II, III, IV

Trumpet I (doubles Piccolo Trumpet), II (doubles Flugelhorn)

Trombone I, II

Bass Trombone

Euphonium

Tuba

String Bass

Harp

Organ

Piano

Timpani

Percussion: Vibraphone, Crotales (4), Orchestra Bells (2),

Xylophone (2), Chimes (3), Gong (5 small, 3 med.), Marimba (2), Suspended Cymbal (3 small, 3 large), Crash Cymbals (2), Bass Drum (2), Wood Block, Anvil (2), Snare Drum, Tenor Drum, Brake Drum (2), Conga, Bongo, Hi-Hat Cymbal, Lion's Roar, Maracas, Tuned Gong (E,Eb), Sleigh Bells, Cabasa, Tom-Toms, Shaker, Castanets, Tambourine

* $\quad$ SATB Chorus, Children's Chorus

* Soprano Soloist, Baritone Soloist

Organ Level: Moderate

Organ Category: Part Required, long chordal sustain, many registration changes 


\section{Meditations on an Old Scottish Hymn}

Robert Jager

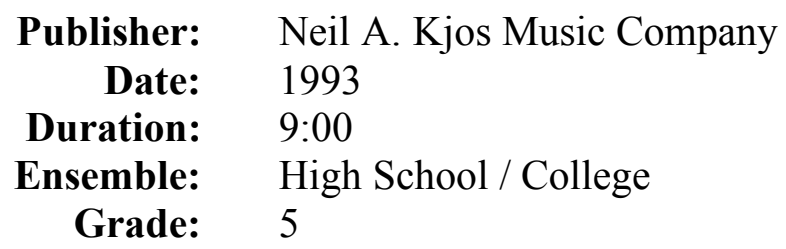

Instrumentation: Piccolo

Flute I, II

Oboe I, II

Eb Clarinet

Bb Clarinet I, II, III

Eb Alto Clarinet

$\mathrm{Bb}$ Bass Clarinet

Eb Contrabass Clarinet

Eb Alto Sax I, II

Bb Tenor Sax

Eb Bari Sax

Bassoon I, II

Horns I, II, III, IV

Solo Trumpet (off-stage)

Trumpet I, II, III

Trombone I, II, III

Euphonium

Tuba

Organ

Timpani

Percussion: Vibraphone, Bells, Bell Tree, Wind Chimes, Suspended Cymbal, Triangle (2), Tam-Tam, Crash Cymbals, Bass Drum

Organ Level: $\quad$ Moderate, requires multiple registration changes Organ Category: $\quad$ Solo Organ, Part Required 
Naviatas!

Don Freund

*Fantasy on Perotin's $12^{\text {th }}$ Century Alleluia

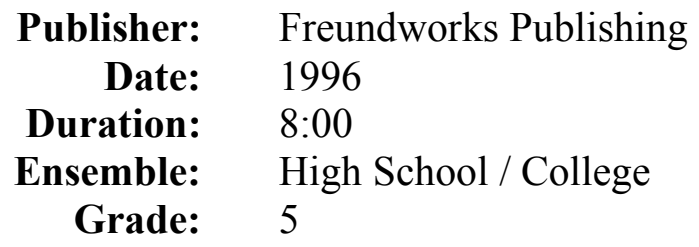

Instrumentation: Piccolo

Flute I, II

Oboe I, II

Eb Clarinet

Bb Clarinet I, II, III

Bb Bass Clarinet

Eb Contrabass Clarinet

Eb Alto Sax I, II

Bb Tenor Sax

Eb Bari Sax

Bassoon I, II

Horns I, II, III, IV

Trumpet I, II, III, IV

Trombone I, II, III

Bass Trombone

Euphonium I, II

Tuba

Organ (or synthesizer)

Piano

Timpani

Percussion: Glockenspiel, Vibraphone, Tambourine, Finger

Cymbals, Chimes, Marimba, Sm. Crash Cymbals, Cowbell, Low Snare Drum, Slit Drum, Tambourine, High Tom, Triangle, Tom-Toms (3), Timbales (2), Suspended Cymbals (2), Bass Drum, Tam-Tam (2), Bongos

Organ Level: $\quad$ Easy, Single-line melody, some chordal

Organ Category: Melody reinforcement, Harmonic reinforcement 


\section{New Day Rising}

Steven Reineke

*Fourth movement of Symphony No. 1, sold individually

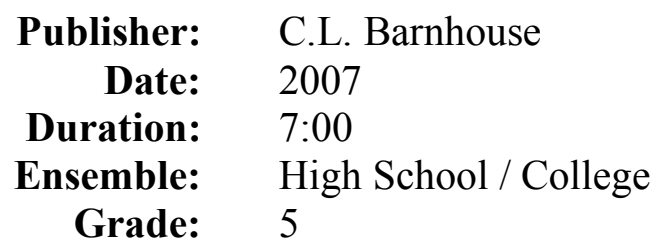

Instrumentation: Piccolo

Flute I, II

Oboe I, II

English Horn

Bb Clarinet I, II, III

Bb Bass Clarinet

Eb Alto Sax I, II

Bb Tenor Sax

Eb Bari Sax

Bassoon I, II

Contrabassoon

Horns I, II, III, IV

Trumpet I, II, III

Trombone I, II, III

Euphonium

Tuba

String Bass

Harp

Organ / Piano

Timpani

Percussion: Suspended Cymbal, Glockenspiel, Chimes, Bass Drum, Tam-Tam

Organ Level: $\quad$ Shared Piano/Organ Part; Easy (Organ), Moderate (Piano)

Organ Category: Chordal, Full Organ 
Niagara Falls

Michael Daugherty

$\begin{aligned} \text { Publisher: } & \text { Peermusic Classical } \\ \text { Date: } & 1997 \\ \text { Duration: } & 10: 00 \\ \text { Ensemble: } & \text { College / Professional } \\ \text { Grade: } & 6\end{aligned}$

Instrumentation: Piccolo

Flute I, II, III, IV

Oboe I, II, III

English Horn

Eb Clarinet

Bb Clarinet I, II, III

$\mathrm{Bb}$ Bass Clarinet

Eb Alto Sax I, II

Bb Tenor Sax

Eb Bari Sax

Bassoon I, II, III

Contrabassoon

Horns I, II, III, IV

Trumpet I, II, III, IV

Trombone I, II, III

Euphonium I, II

Tuba I, II

String Bass

Harp

Organ/Synthesizer

Timpani

Percussion: Glockenspiel, Vibraphone, Xylophone, Marimba, Chimes, Bell Tree, Wind Chimes, Triangle (3), Medium Ship Bell, Claves, Bass Drum, Suspended Cymbal, Tambourine, Large Crash Cymbal, High Congas, High Bongos, Vibraslap, Whip, Ratchet

Organ Level: $\quad$ Moderate, Mix of Sustain and Chorale-Like Passages Organ Category: $\quad$ Part Required, Registration Changes 
$\begin{aligned} \text { Publisher: } & \text { Maecenas Music } \\ \text { Date: } & 2009 \\ \text { Duration: } & 39: 00 \\ \text { Ensemble: } & \text { College / Professional } \\ \text { Grade: } & 6\end{aligned}$

Instrumentation: Piccolo, Flute I, II Oboe I, II, English Horn

Eb Clarinet

Bb Clarinet I, II, III

Bb Bass Clarinet

Bb Contrabass Clarinet

Eb Alto Sax I, II

$\mathrm{Bb}$ Tenor Sax

Eb Bari Sax

$*$

$*$

Bass Saxophone

Contrabass Saxophone/Tubax

Bassoon I, II, Contrabassoon

Horns I, II, III, IV

Trumpet I, II, III, IV

$*$

Bass Trumpet in $\mathrm{C}$

Trombone I, II

Bass Trombone

Euphonium

Basses

String Bass

Harp/Keyboard

Organ

Piano/Celesta

* $\quad$ SATB Chorus / Baritone Soloist

Timpani/Boomwhacker

Percussion: 4 Bell Plates, 2 Tuned Gongs, Glockenspiel,

Crotales (2), Xylophone, Tubular Bells, Vibraphone Marimba, Bass Drum, Snare Drum, Tenor Drum, Tom-Toms (2), Tam-Tam (2), Triangle (2), Tambourine (2), Cymbals (3), Suspended Cymbal, Cabasa, Sandpaper Blocks, Wood Blocks (2), Mark Tree, Bell Tree, Cowbell, Bongos, Anvil, Brake Drum, Ratchet, Whip (Very Large)

Organ Level: Moderate

Organ Category: $\quad$ Part Required, ad lib., but strongly encouraged 


\section{Passacaglia (Homage on B-A-C-H)}

Ron Nelson

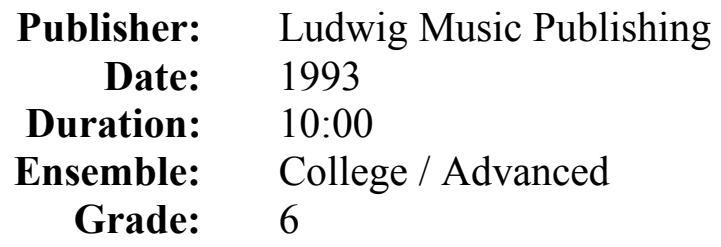

Instrumentation: Piccolo

Flute I, II, III (Alto Flute)

Oboe I, II

English Horn

Bb Clarinet I - XII

Bb Bass Clarinet

Eb Alto Sax I, II

$\mathrm{Bb}$ Tenor Sax

Eb Bari Sax

Bassoon I, II, Contrabassoon

Horns I, II, III, IV

Trumpet I, II, III, IV, V, VI

Trombone I, II, III, IV

Euphonium I, II

Tuba

String Bass

Organ (Synthesizer simulating Organ)

Piano

Timpani

Percussion I, II, III, IV Bass Drum, Bongos, Crotales, Suspended Cymbals (2), Bells, Gong, Marimba, Slapstick, Snare Drum, Temple Block, Tenor Drum, Tom-Tom, Chimes, Vibraphone, Xylophone

Organ Level: $\quad$ Easy, used only for pedal voice

Organ Category: Calls for synthesizer simulating organ 


\title{
Pilatus: Mountain of Dragons
}

Steven Reineke

\author{
Publisher: C.L. Barnhouse \\ Date: 2002 \\ Duration: $\quad$ 10:00 \\ Ensemble: High School / College \\ Grade: 4 \\ Instrumentation: Piccolo \\ Flute I \\ Oboe \\ Bb Clarinet I, II, III \\ Bb Bass Clarinet \\ $\mathrm{Bb}$ Contrabass Clarinet \\ Eb Alto Sax I, II \\ Bb Tenor Sax \\ Eb Bari Sax \\ Bassoon \\ Horns I, II \\ Trumpet I, II, III \\ Trombone I, II, III \\ Euphonium \\ Tuba \\ String Bass \\ Harp \\ Organ (optional) \\ Timpani \\ Percussion: Crash Cymbals, Suspended Cymbals, Snare Drum, \\ Bass Drum, Chimes, Bell Tree, Mark Tree, Brake \\ Drum, Hi-Hat, Lg. Tam-Tam, Glock, Xylophone, \\ Chimes
}

Organ Level: Moderate

Organ Category: $\quad$ Optional, Full Registration, Grand Finale, Hymn-like Harmonic Reinforcement 


\title{
Polish Christmas Music
}

Johan de Meij

\author{
Publisher: Hal Leonard / Amstel Publications \\ Date: 1995 \\ Duration: 11:30 \\ Ensemble: High School / College \\ Grade: $\quad 4$ \\ Instrumentation: Piccolo \\ Flute I, II \\ Oboe I, II \\ English Horn \\ Eb Clarinet \\ Bb Clarinet I, II, III \\ Eb Alto Clarinet \\ $\mathrm{Bb}$ Bass Clarinet \\ Eb Alto Sax I, II \\ Bb Tenor Sax \\ Eb Bari Sax \\ Bassoon I, II \\ Horns I, II, III, IV \\ Trumpet I, II, III \\ Trombone I, II, III \\ Euphonium \\ Tuba \\ String Bass \\ Harp (ad lib.) \\ Organ (ad lib.) \\ SATB Chorus (ad lib.) \\ Timpani \\ Percussion: Chimes, Suspended Cymbal, Bells, Sleigh Bells, \\ Glass Chimes, Deep Tom-Tom, Bass Drum, Snare \\ Drum \\ Organ Level: $\quad$ Easy, Chorale-like \\ Organ Category: Optional, Grand Finale, Full Organ
}




\title{
Prophecy of the Earth
}

\author{
Publisher: C. Alan Publications \\ Date: 1993 \\ Duration: 11:00 \\ Ensemble: College / Professional \\ Grade: 5 \\ Instrumentation: Piccolo \\ Flute I, II \\ Oboe I, II \\ Bb Clarinet I, II, III \\ $\mathrm{Bb}$ Bass Clarinet \\ Eb Alto Sax I, II \\ Bb Tenor Sax \\ Eb Bari Sax \\ Bassoon I, II \\ Horns I, II, III, IV \\ Trumpet I, II, III \\ Trombone I, II, III \\ Bass Trombone \\ Euphonium \\ Tuba \\ Organ \\ Harp \\ Timpani \\ Percussion: Chimes, Vibraphone, Bells, Crotales, Crash \\ Cymbals, Tam-Tam, Marimba, Tom-Tom (3), \\ Small Bass Drum, Snare Drum, Roto-Toms (6), \\ Suspended Cymbal
}

Organ Level: Advanced

Organ Category: Solo Organ, Registration Changes $(p p-f f)$ 


\author{
Publisher: Knightwind Music \\ Date: 2015 \\ Duration: $\quad 2: 30$ \\ Ensemble: High School / College \\ Grade: 5 \\ Instrumentation: Piccolo \\ Flute \\ Oboe \\ Bb Clarinet I, II, III \\ $\mathrm{Bb}$ Bass Clarinet \\ Eb Alto Sax I, II \\ $\mathrm{Bb}$ Tenor Sax \\ Eb Bari Sax \\ Bassoon \\ Horns I, II, III, IV \\ Trumpet I, II, III \\ Trombone I, II, III \\ Euphonium \\ Tuba \\ Organ \\ Timpani \\ Percussion: Triangle, Bass Drum, Cymbals, Chimes, \\ Orchestra Bells, Vibraphone
}

Organ Level: $\quad$ Moderate

Organ Category: Part Required, Solo Organ 


\section{Resonances I}

Ron Nelson

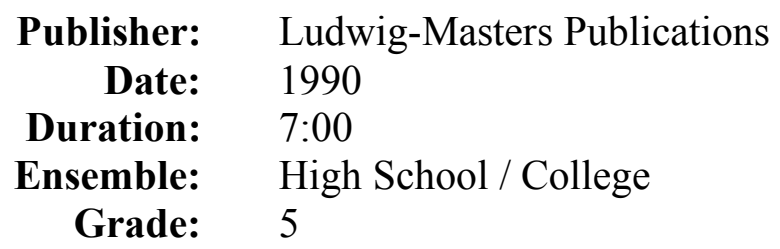

Instrumentation: Piccolo/Flute

Oboe I, II

Bb Clarinet I, II, III, IV, V, VI, VII, VIII

$\mathrm{Bb}$ Bass Clarinet

Eb Alto Sax I, II

Bb Tenor Sax

Eb Bari Sax

Bassoon I, II

Horns I, II, III, IV

Trumpet I, II, III, IV

Trombone I, II, III, IV

Euphonium

Tuba

String Bass

Organ (optional)

Timpani

Percussion: Bass Drum, Bell Tree, Crotales, Glockenspiel, Gong, Suspended Cymbal

Organ Level: Moderate, chordal, some aleatoric, registration changes Organ Category: Optional, but strongly recommended 


\title{
Riften Wed
}

Julie Giroux

\author{
Publisher: Musica Propria \\ Date: 2013 \\ Duration: $\quad$ 7:00 \\ Ensemble: High School / College \\ Grade: 4 \\ Instrumentation: Piccolo \\ Flute I, II \\ Oboe I, II \\ English Horn \\ Bb Clarinet I, II, III \\ $\mathrm{Bb}$ Bass Clarinet \\ Eb Contralto Clarinet \\ $\mathrm{Bb}$ Contrabass Clarinet \\ Eb Alto Sax I, II \\ Bb Tenor Sax \\ Eb Bari Sax \\ Bassoon I, II \\ Contrabassoon \\ Horns I, II, III, IV \\ Trumpet I, II, III \\ Trombone I, II, III \\ Bass Trombone \\ Euphonium \\ Tuba \\ String Bass \\ Harp (not optional) \\ Organ (optional) \\ Timpani \\ Percussion: Orchestra Bells, Tubular Bells, Vibraphone, \\ Crash Cymbals, Suspended Cymbal, Bass Drum
}

Organ Level: $\quad$ Easy, Choral-like

Organ Category: Optional, Cross-cued in parts 


\section{Sails of Time}

David Gillingham

$\begin{aligned} \text { Publisher: } & \text { C. Alan Publications } \\ \text { Date: } & 2007 \\ \text { Duration: } & 10: 00 \\ \text { Ensemble: } & \text { High School / College } \\ \text { Grade: } & 5\end{aligned}$

Instrumentation: Piccolo

Flute I, II

Oboe I, II

Bb Clarinet I, II, III

$\mathrm{Bb}$ Bass Clarinet

Eb Alto Sax I, II

$\mathrm{Bb}$ Tenor Sax

Eb Bari Sax

Bassoon I, II

Horns I, II, III, IV

Trumpet I, II, III

Trombone I, II

Bass Trombone

Euphonium

Tuba

Organ (optional)

Piano

Timpani

Percussion: Crotales, Xylophone, Chimes, Bells, Sus. Cymbal, Slapstick, Temple Blocks, Brake Drum, Tam-Tam, Vibraphone, Concert Toms (3), Small Bass Drum, Snare Drum, Crash Cymbals, Marimba, Large Link Chain, Bass Drum

Organ Level: $\quad$ Moderate, some technique, could be split with piano Organ Category: Optional

* Originally composed for a massed band of 3 separate ensembles, but well suited to one ensemble as well. 


\section{Salmo della Rinascita}

Anthony LaBounty

$\begin{aligned} \text { Publisher: } & \text { TRN Publications } \\ \text { Date: } & 2014 \\ \text { Duration: } & 8: 00 \\ \text { Ensemble: } & \text { High School / College } \\ \text { Grade: } & 4\end{aligned}$

Instrumentation: Flute I, II, III, IV

Oboe I, II

English Horn

Bb Clarinet I, II, III, IV, V, VI

Bb Bass Clarinet

$\mathrm{Bb}$ Contrabass Clarinet (optional)

Eb Alto Sax I, II

$\mathrm{Bb}$ Tenor Sax

Eb Bari Sax

Bassoon I, II

Horns I, II, III, IV

Trumpet I, II, III, IV

Trombone I, II, III

Euphonium I, II

Tuba I, II

String Bass (optional)

Organ (optional)

Timpani

Percussion: Marimba, Vibraphone, Bass Drum, Glockenspiel, Crotales, Suspended Cymbal, Triangle, Mark Tree, Tam-Tam

Organ Level: $\quad$ Easy, Chorale-like

Organ Category: Optional, Enhancing sonority 


\section{The Seafarer - A Nautical Rhapsody}

Hayden Wood

*New edition available, omits organ part

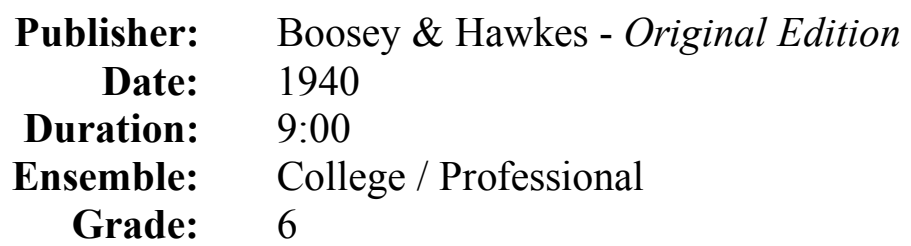

Instrumentation: Db Piccolo

Flute I, II, III

Oboe I, II

Eb Clarinet

Bb Clarinet I, II, III

$\mathrm{Eb}$ Alto Clarinet

$\mathrm{Bb}$ Bass Clarinet

Bb Contrabass Clarinet

Eb Alto Sax

Bb Tenor Sax

Eb Bari Sax

Bb Bass Saxophone

Bassoon I, II

Horns I, II, III, IV

Cornet I, II

Flugelhorn I, II

Trombone I, II

Bass Trombone

Euphonium

Tuba

String Bass

Harp

Organ

Timpani

Drums

Organ Level: $\quad$ Moderate, Chorale-like

Organ Category: $\quad$ Optional, Grand Finale, Melodic \& Harmonic Reinforcement 


\title{
Slava! A Celebration for Band
}

Joel Blahnik

\author{
Publisher: Alliance Publications / Fred Bock Publishers \\ Date: 1998 \\ Duration: $\quad$ 7:00 \\ Ensemble: High School / College \\ Grade: 5 \\ Instrumentation: Piccolo \\ Flute I, II \\ Oboe I, II \\ Bb Clarinet I, II, III \\ Bb Bass Clarinet \\ Eb Alto Sax I, II \\ Bb Tenor Sax \\ Eb Bari Sax \\ Bassoon I, II \\ Horns I, II, III, IV \\ Trumpet I, II, III \\ Trombone I, II \\ Euphonium \\ Tuba \\ Organ (optional) \\ Timpani \\ Percussion: Cymbals, Glockenspiel, Gong, Snare Drum, \\ Tubular Bells
}

Organ Level: $\quad$ Easy, Two-Stave

Organ Category: Antiphonal Organ preferred, Optional, Grand Finale 


\title{
Sonata Da Chiesa for Organ and Concert Band
}

Kees Schoonenbeek

\author{
Publisher: De Haske Publications \\ Date: 2003 \\ Duration: 19:00 \\ Movements: 3 \\ Ensemble: High School / College \\ Grade: $\quad 4$ \\ Instrumentation: Flute \\ Oboe \\ Bb Clarinet I, II, III \\ Bb Bass Clarinet \\ $\mathrm{Bb}$ Contrabass Clarinet \\ Eb Alto Sax \\ $\mathrm{Bb}$ Tenor Sax \\ Eb Bari Sax \\ Bassoon \\ Horns I, II \\ Trumpet I, II, III \\ Trombone I, II, III \\ Euphonium \\ Tuba I, II \\ Organ solo \\ Timpani \\ Percussion: Bells, Suspended Cymbal, Snare Drum, Crash \\ Cymbals, Bass Drum
}

Organ Level: $\quad$ Advanced, multiple registrations

Organ Category: Part Required, Solo Organ 


\title{
Songs and Refrains
}

Daniel Basford

\author{
Publisher: Maecenas Music \\ Date: 2006 \\ Duration: 20:00 I. Arkendale \\ Movements: 4 \\ Ensemble: High School / College \\ II. Strawberry Fair \\ Grade: 5 \\ Instrumentation: Piccolo \\ Flute I, II \\ Oboe I, II \\ English Horn \\ Eb Clarinet \\ Bb Clarinet I, II, III \\ $\mathrm{Bb}$ Bass Clarinet \\ $\mathrm{Bb}$ Contrabass Clarinet \\ III. The Night Watch \\ IV. Dashing Away with the \\ Smoothing Iron \\ Eb Alto Sax I, II \\ Bb Tenor Sax \\ Eb Bari Sax \\ Bassoon I, II, III \\ Horns I, II, III, IV \\ Trumpet I, II, III, IV \\ Trombone I, II \\ Bass Trombone \\ Euphonium \\ Tuba \\ Harp (or keyboard) \\ Organ (ad lib.) \\ Celesta (or keyboard) \\ Timpani \\ Percussion: Xylophone, Glockenspiel, Tubular Bells, Marimba, \\ Bass Drum, Snare Drum, Tenor Drum, Crash \\ Cymbals, Sus. Cymbal, Triangle, Tam-Tam, Finger \\ Cymbals, Castanets, Mark Tree, Anvil, Whip, \\ Ratchet
}

Organ Level: $\quad$ Easy, pedal-point, some chorale-like passages Organ Category: Optional (ad lib.) 


\title{
Symphony for Wind Ensemble
}

Tyler Harrison

\author{
Publisher: Tyler Harrison Music \\ Date: $\quad 2017$ \\ Duration: $\quad 31: 00$ \\ Movements: 3 \\ Ensemble: College / Professional \\ Grade: 6 \\ Instrumentation: Piccolo \\ Flute I, II \\ Oboe I, II \\ Eb Clarinet \\ Bb Clarinet I, II, III \\ $\mathrm{Bb}$ Bass Clarinet \\ $\mathrm{Bb}$ Contrabass Clarinet \\ Bb Soprano Saxophone \\ Eb Alto Sax I, II \\ $\mathrm{Bb}$ Tenor Sax \\ Eb Bari Sax \\ Bassoon \\ Contrabassoon \\ Horns I, II, III, IV \\ Trumpet I, II, III \\ Trombone I, II \\ Bass Trombone \\ Euphonium \\ Tuba \\ String Bass \\ Organ (Preferably Large Pipe Organ) \\ Piano \\ Timpani \\ Percussion I, II, III, IV
}

Organ Level: $\quad$ Moderate, Registration Changes, Chordal, Some Technique

Organ Category: $\quad$ Organ Preferred, Keyboard Part Available 


\section{Symphony No. 1 -Omnes Gentes}

$\begin{array}{rll}\text { Publisher: } & \text { Brett Abigaña Music } & \\ \text { Date: } & 2009 & \text { Movements } \\ \text { Duration: } & 30: 00 & \text { I. Prelude } \\ \text { Movements: } & 4 & \text { II. Degeneration } \\ \text { Ensemble: } & \text { College / Professional } & \text { III. Benediction } \\ \text { Grade: } & 6 & \text { IV. Motet }\end{array}$

Instrumentation: Piccolo

Flute I, II

Oboe I, II (English Horn)

Eb Clarinet

Bb Clarinet I, II, III

$\mathrm{Bb}$ Bass Clarinet

$\mathrm{Bb}$ Contrabass Clarinet

Eb Alto Sax I, II

$\mathrm{Bb}$ Tenor Sax

Eb Bari Sax

Bassoon I, II

Horns I, II, III, IV

Trumpet I, II, III, IV (Antiphonal V, VI)

Trombone I, II, III, IV

Euphonium

Tuba

String Bass

Harp

Organ

Timpani

Percussion: Chimes, Vibraphone, Triangle, Xylophone, Crotales, Glockenspiel, Crash Cymbals, Sus. Cymbal, Snare Drum, Marimba, Bell Tree, Mark Tree, Tam-Tam, Bass Drum

* Soprano Solo (Offstage)

* SATB Choir

Organ Level: Moderate, simultaneous dynamic/registration changes Organ Category: Part required (Mvmts. III, IV), chordal, harmonic reinforcement Grand Finale 


\section{Symphony No. 4}

David Maslanka

$\begin{aligned} \text { Publisher: } & \text { Carl Fischer } \\ \text { Date: } & 1994 \\ \text { Duration: } & 28: 00 \\ \text { Ensemble: } & \text { College / Professional } \\ \text { Grade: } & 6+\end{aligned}$

Instrumentation: Piccolo

Flute I, II

Alto Flute

Oboe I, II, III

Eb Clarinet

Bb Clarinet I, II, III

Bb Bass Clarinet

$\mathrm{Bb}$ Contrabass Clarinet

Eb Alto Sax I, II

Bb Tenor Sax

Eb Bari Sax

Bassoon I, II

Contrabassoon

Horns I, II, III, IV

Trumpet (in C) I, II, III

Trombone I, II, III

Bass Trombone

Euphonium I, II

Tuba I, II

String Bass

Harp

Organ

Piano

Timpani

Percussion: Anvil, Bass Drum, Bongos, Bull Roar, Crotales, Crash Cymbals, Suspended Cymbals (3), Marimba, Glockenspiel, Tam-Tam (6), Piccolo Snare Drum, Shaker, Snare Drum, Tenor Drum, Tom-Toms, Tubular Bells, Vibraphone (bowed), Wood Block, Xylophone

Organ Level: Advanced

Organ Category: $\quad$ Grand Finale, Full Organ 
$\begin{aligned} \text { Publisher: } & \text { Manhattan Beach Music } \\ \text { Date: } & 1981 \\ \text { Duration: } & 23: 00 \\ \text { Ensemble: } & \text { High School / College } \\ \text { Grade: } & 5\end{aligned}$

Instrumentation: Piccolo

Flute I, II

Alto Flute in $\mathrm{G}$

Bass Flute

Oboe I, II (Tenor Recorder)

English Horn

Eb Clarinet

Bb Clarinet I, II, III

Eb Alto Clarinet

$\mathrm{Bb}$ Bass Clarinet

Eb Contrabass Clarinet

Bb Contrabass Clarinet

Bb Soprano Saxophone

Eb Alto Sax I, II

Bb Tenor Sax

Eb Bari Sax

Bassoon I, II

Contrabassoon

Horns I, II, III, IV

Trumpet I, II, III

Flugelhorn I, II, III (or cornet)

Bb Bass Trumpet

Trombone I, II, III

Euphonium (Optional)

Tuba

String Bass

Harp

Organ

Timpani

\section{Percussion}

Amer. Indian Drum

Bass Drum

Bell Tree

Bongos

Castagnettes

Claves

Coconut Shells

Conga

Cymbal - Sus (3)

Cymbal - Crash (5)

Drums (4)

Dumbek

Field Drum

Finger Cymbals (2)

Frame Drum

Glockenspiel

Marimba I, II, III

Snare (piccolo)

Snare (regular)

Tam-Tam (2)

Tambourine (3)

Temple Blocks

Tenor Drum

Tom-Tom

Triangle (4)

Tubular Bells

Vibraslap

Whip

Xylophone

Organ Level: Moderate

Organ Category: Solo Organ, Solo cued, but organ preferred 


\section{Tatelestai}

Andrew Boss

Publisher: Murphy Music Press

Date: 2014

Duration: 27:00

Ensemble: College / Professional

Grade: 6

Instrumentation: Piccolo

Flute I, II

Oboe I, II

Bb Clarinet I, II, III

$\mathrm{Bb}$ Bass Clarinet

$\mathrm{Bb}$ Contrabass Clarinet

Bb Soprano Sax

Eb Alto Sax

Bb Tenor Sax

Eb Bari Sax

Bassoon I, II

Contrabassoon

Horns I, II, III, IV

Trumpet I, II, III, IV

Trombone I, II, III

Bass Trombone

Euphonium

Tuba

String Bass

Harp

Organ (Finale only, optional but encouraged)*

Piano/Celesta

Timpani

Percussion: Snare Drum (3), Bongos, Tom-Toms (4), Lg. Sus. Cymbal, Med. Sus. Cymbal (2), Crash Cymbals, Bass Drums, congas, Sm. Tam-Tam, glockenspiel, Chimes, Anvil, Triangle, Log Drum, Tambourine, Marimba, Xylophone, Vibraphone, Temple Blocks, Crotales (2 octaves)

Organ Level: Moderate Organ Category: Optional, but preferred
*If organ is not available, use optional antiphonal brass choir of 3 horns, 3 trumpets. 


\author{
Publisher: Markowski Creative (ASCAP) \\ Date: 2018 \\ Duration: $\quad$ 7:00 \\ Ensemble: College / Professional \\ Grade: 6 \\ Instrumentation: Piccolo \\ Flute I, II \\ Oboe I, II \\ Eb Clarinet \\ Bb Clarinet I, II, III \\ Bb Bass Clarinet \\ $\mathrm{Bb}$ Contrabass Clarinet \\ Eb Alto Sax I, II \\ Bb Tenor Sax \\ Eb Bari Sax \\ Bassoon I, II \\ Horns I, II, III, IV \\ Trumpet I, II, III \\ Trumpet Solo I, II, III \\ Trombone I, II \\ Bass Trombone \\ Euphonium I, II \\ Tuba I, II \\ Organ (optional) \\ Timpani \\ Percussion: Suspended Trash Cymbal, Snare Drum, \\ Glockenspiel, Chimes, Tam-Tam, Triangle, \\ Marimba, Crash Cymbals, Concert Toms (2), \\ Xylophone, Vibraphone, Suspended Cymbal, \\ Bass Drum
}

Organ Level: Moderate

Organ Category: Optional, Full Grand Finale 


\section{The Power of Rome and the Christian Heart}

Publisher: Ludwig-Masters Publications

Date: 1953

Duration: 13:00

Ensemble: College / Professional

Grade: 5

Instrumentation: Piccolo I, II

Flute I, II

Oboe I, II

English Horn

Eb Clarinet

Bb Clarinet I, II, III

Eb Alto Clarinet

$\mathrm{Bb}$ Bass Clarinet

$\mathrm{Bb}$ Contrabass Clarinet

Bb Soprano Sax

Eb Alto Sax I, II

$\mathrm{Bb}$ Tenor Sax

Eb Bari Sax

Bb Bass Saxophone

Bassoon I, II

Optional Tuneful Percussion

Horns I, II, III, IV

Trumpet I, II, III

Trombone I, II, III

Euphonium/Baritone

Tuba (the more the better)

Glockenspiel

Xylophone

Swiss Hand Bells

Wooden Marimba

Metal Marimba

Harp(s) - The more harps the better

Pipe of Electric Organ

Piano(s) - The more pianos the better

Celesta and/or Dulcitone

Timpani

Percussion: Side Drum, Bass Drum, Gong, Cymbals

Organ Level: $\quad$ Advanced, some registration provided

Organ Category: Part Required, Piano may substitute if no organ available 


\title{
Variations on God of Our Fathers
}

Tim Rumsey

\author{
Publisher: Laudation Music / J.W. Pepper \\ Date: 2009 \\ Duration: $\quad 8: 30$ \\ Ensemble: High School / College \\ Grade: 5 \\ Instrumentation: Piccolo \\ Flute I, II \\ Oboe I, II \\ Eb Clarinet \\ Bb Clarinet I, II, III \\ Eb Alto Clarinet \\ $\mathrm{Bb}$ Bass Clarinet \\ Eb Alto Sax I, II \\ $\mathrm{Bb}$ Tenor Sax \\ Eb Bari Sax \\ Bassoon I, II \\ Horns I, II, III, IV \\ Trumpet I, II, III, IV, V \\ Trombone I, II \\ Bass Trombone \\ Euphonium I, II \\ Tuba \\ Organ \\ Timpani \\ Percussion: Snare Drum, Bass Drum, Triangle, Suspended \\ Cymbal, Crash Cymbal, Tambouring, Gong, \\ Marimba, Xylophone, Chimes, Glockenspiel
}

Organ Level: $\quad$ Easy, Chordal, Choral-like

Organ Category: Introduction, Fourth (final) Variation, Grand Finale 


\section{Veni Emmanuel}

Jesse Ayers

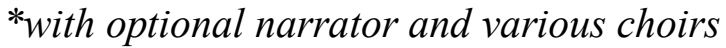

$\begin{aligned} \text { Publisher: } & \text { Jesse Ayers Music } \\ \text { Date: } & 2014 \\ \text { Duration: } & 10: 15 \\ \text { Ensemble: } & \text { High School / College } \\ \text { Grade: } & 4\end{aligned}$

Instrumentation: Piccolo

Flute I, II

Oboe

$\mathrm{Bb}$ Clarinet I, II

$\mathrm{Bb}$ Bass Clarinet

$\mathrm{Bb}$ Contrabass Clarinet (optional)

Eb Alto Sax I, II

$\mathrm{Bb}$ Tenor Sax

Eb Bari Sax

Bassoon

Horns I, II, III, IV

Trumpet I, II, III

Trombone I, II

Bass Trombone

Euphonium

Tuba

String Bass

Harp

Organ/Electronic Keyboard (optional)

Piano (optional)

Timpani

Percussion: Marimba, Glockenspiel, Vibraphone, Chimes, Crash Cymbals, Suspended Cymbal, Tam-Tam

Organ Level: $\quad$ Easy

Organ Category: Organ preferred, cross-cued in other parts

* Orchestral Version Available

** Orchestra and Band versions are in the same key and can be performed together. 


\author{
Publisher: De Haske Publications \\ Date: 2007 \\ Duration: 5:00 \\ Ensemble: Middle School / High School \\ Grade: 3 \\ Instrumentation: Piccolo \\ Flute I, II \\ Oboe I, II \\ English Horn \\ Eb Clarinet \\ Bb Clarinet I, II, III \\ Eb Alto Clarinet \\ $\mathrm{Bb}$ Bass Clarinet \\ $\mathrm{Bb}$ Contrabass Clarinet \\ Eb Alto Sax I, II \\ Bb Tenor Sax \\ Eb Bari Sax \\ Bassoon I, II, III \\ Horns I, II, III, IV \\ Trumpet I, II, III \\ Trombone I, II, III \\ Euphonium \\ Tuba \\ String Bass \\ Harp \\ Organ \\ Timpani \\ Percussion: Bass Drum, Snare Drum, Glockenspiel, Triangle, \\ Crash Cymbals, Xylophone, Suspended Cymbal
}

Organ Level: $\quad$ Easy, 2-stave

Organ Category: $\quad$ Part Required, Grand Finale, Chorale-like 


\title{
Ye Banks and Braes O' Bonnie Doon \\ Percy Grainger \\ *Originally written for Men's Chorus and Whistler, transcribed for band by composer
}

\author{
Publisher: G. Schirmer / J.W. Pepper \\ Date: 1936 \\ Duration: 3:00 \\ Ensemble: High School / College \\ Grade: 4 \\ Instrumentation: Piccolo \\ Flute I, II \\ Oboe I, II \\ English Horn \\ Eb Clarinet \\ Bb Clarinet I, II, III, IV \\ Eb Alto Clarinet \\ $\mathrm{Bb}$ Bass Clarinet \\ Eb Alto Sax I, II \\ Bb Tenor Sax I, II \\ Eb Bari Sax I, II \\ Bassoon I, II, III \\ Horns I, II, III, IV \\ Cornet I, II, III \\ Trumpet I, II \\ Flugelhorn I, II (optional) \\ Trombone I, II, III \\ Euphonium \\ Tuba \\ String Bass \\ Organ (or Harmonium)
}

Organ Level: Moderate

Organ Category: Optional organ or harmonium 


\section{SELECTED WORKS NOT MEETING CRITERIA BUT SHOULD BE MENTIONED}

Throughout the course of this research project, many pieces were discovered that, for one reason or another, fell just outside the scope and delimitation of this study. In many cases, the instrumentation did not fit the minimum requirements to reasonably say the work was for concert band. Some of these works were written for Wind Orchestra, the instrumentalists from the symphony orchestra minus the string section. With this classification, often the saxophones and euphoniums are left out of the instrumentation. The compositions that follow deserve recognition and are fine works for wind instruments and organ.

\section{Concerto for Organ, Winds, and Percussion}

Marco Pütz

$\begin{array}{rll}\text { Publisher: } & \text { Edition Kunzelmann }(\mathrm{CH}) & \\ \text { Date: } & 2015 & \text { Movements } \\ \text { Duration: } & 27: 00 & \text { I. Praeludium } \\ \text { Movements: } & 4 & \text { II. Scherzo } \\ \text { Ensemble: } & \text { College / Professional } & \text { III. Adagio } \\ \text { Grade: } & 6 & \text { IV. Toccata }\end{array}$

$\begin{array}{lll}\text { Instrumentation: } & \text { Piccolo } & \text { Horns I, II, III, IV } \\ & \text { Flute I, II } & \text { Trumpet I, II, III } \\ & \text { Oboe I, II } & \text { Trombone I, II, III } \\ & \text { Eb Clarinet } & \text { Bass Trombone } \\ & \text { Bb Clarinet I, II, III } & \text { Tuba } \\ & \text { Bb Bass Clarinet } & \text { String Bass } \\ & \text { Eb Alto Sax I, II } & \text { Organ } \\ \text { Bassoon I, II } & \\ \text { Contrabassoon } & \text { Percussion I, II, III \& Mallets }\end{array}$

\footnotetext{
Organ Level: $\quad$ Advanced Organ Category: Solo, Organ Concerto

Disqualification: No Tenor or Baritone Saxophone, No Euphonium
} 


\title{
Concerto for Wind Orchestra, Percussion, and Organ
}

Ivana Loudová

\author{
Publisher: $\quad$ C.F. Peters \\ Date: 1974 \\ Duration: 12:00 \\ Ensemble: College / Professional \\ Grade: 6 \\ Instrumentation: Piccolo \\ Flute I, II, III, IV \\ Oboe I, II, III, IV \\ Bb Clarinet I, II, III, IV \\ $\mathrm{Bb}$ Bass Clarinet \\ Bassoon I, II, III, IV \\ Horns I, II, III, IV \\ Trumpet I, II, III, IV \\ Trombone I, II, III, IV \\ Tuba \\ Organ \\ Timpani \\ Percussion: Tom-Toms (3), Triangle (3), Crotales, Suspended \\ Cymbals (6), Tam-Tam (3), Wood Block, Temple \\ Blocks (4)
}

Organ Level: Advanced

Organ Category: Aleatoric, Part Required

Disqualification: No Saxophones, No Euphoniums 


\title{
Concerto for Piano, Winds, and Percussion
}

David Maslanka

\author{
Publisher: Carl Fischer \\ Date: $\quad 1976$ \\ Movements \\ Duration: 20:00 \\ Movements: 3 \\ Ensemble: College / Professional \\ Grade: 5 \\ I. Moderate, with Heavy Energy \\ II. Slow - Dance Fantasy \\ III. Fast, Aggressive \\ Instrumentation: Flute I, II (Piccolo) \\ Oboe I, II (English Horn) \\ Eb Clarinet \\ Bb Clarinet I, II \\ $\mathrm{Bb}$ Bass Clarinet \\ $\mathrm{Bb}$ Contrabass Clarinet \\ Bassoon I, II \\ Horns I, II, III, IV \\ Trumpet I, II \\ Trombone I, II \\ Tuba \\ String Bass \\ Electric Organ \\ Solo Piano \\ Percussion: Xylophone, Marimba, Vibraphone, Orchestra \\ Bells, Snare Drum, Tom-Toms (3), Bass Drum, \\ Bongos (2), Wood Blocks (3), Temple Blocks, \\ Suspended Cymbal (2), Crash Cymbal, Tam-Tams, \\ Triangle, Ratchet, Anvil
}

Organ Level: $\quad$ Score not available for evaluation at time of publishing. Organ Category: $\quad$ Score not available for evaluation at time of publishing.

Disqualification: No Saxophones, No Euphoniums 


\section{Dunhuang Fantasy for Organ and Wind Ensemble}

Chen $Y i$

$\begin{aligned} \text { Publisher: } & \text { Theodore Presser Company } \\ \text { Date: } & 1999 \\ \text { Duration: } & 12: 00 \\ \text { Ensemble: } & \text { College / Professional } \\ \text { Grade: } & 6\end{aligned}$

Instrumentation: Flute

Oboe

$\mathrm{Bb}$ Clarinet

$\mathrm{Bb}$ Bass Clarinet

Double Bassoon

Horn

Trumpet

Trombone

Tuba

Organ

Percussion: Mark Tree, Bongos (2)

Organ Level: Advanced

Organ Category: Organ Solo

Disqualification: No Saxophones, No Euphonium 


\author{
Publisher: Bärenreiter Press \\ Date: 1966 \\ Duration: 18:00 \\ Movements: 7 \\ Ensemble: College / Advanced \\ Grade: 6 \\ Instrumentation: Piccolo \\ Flute I, II \\ Oboe I, II \\ English Horn \\ Clarinet in A I, II \\ $\mathrm{Bb}$ Bass Clarinet \\ Eb Alto Sax (solo only) \\ $\mathrm{Bb}$ Tenor Sax (solo only) \\ Bassoon I, II, III \\ Contrabassoon \\ Horns I, II, III, IV \\ Trumpet I, II, III \\ Combo Section \\ Trombone I, II, III \\ $\mathrm{Bb}$ Clarinet \\ Euphonium (Optional) \\ Cornetto in $\mathrm{Bb}$ \\ Tuba \\ Electric Guitar \\ Electric Bass \\ String Bass (4) \\ Harp \\ Guitar I / Mandolin \\ Guitar II / Mandolin / Electric Guitar \\ Organ \\ Piano/Celesta \\ Timpani \\ Percussion I, II, III \\ Organ Level: $\quad$ Moderate \\ Organ Category: Part Required, Mvt. I \& VII only \\ Disqualification: No Full Saxophone Ensemble, Solo Instruments only
}




\section{Polka and Fugue from "Schwanda, the Bagpiper"}

Jaromir Weinberger / Transcribed and Adapted for Band by Glenn C. Bainum

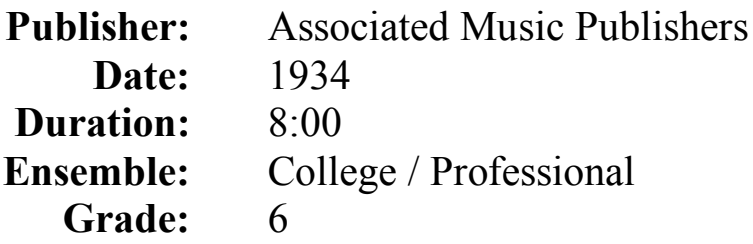

Instrumentation: Piccolo

Flute I, II, III

Oboe I, II

Eb Clarinet

Bb Clarinet I, II, III, IV

Eb Alto Clarinet

Bb Bass Clarinet

Bb Contrabass Clarinet

Bb Soprano Sax

Eb Alto Sax

$\mathrm{Bb}$ Tenor Sax

Eb Bari Sax

Bb Bass Sax

Bassoon I, II

Contrabassoon

Horns I, II, III, IV

Cornet I, II

Trumpet I, II

Flugelhorn I, II

Bb Herald Trumpets (4)

Trombone I, II, III

Euphonium

Tuba

String Bass

Harp

Organ (ad lib.)

Timpani

Percussion: Snare Drum, Bass Drum, Triangle, Cymbals, Chimes

Organ Level: $\quad$ Moderate, mostly chordal, some technical passages in finale Organ Category: $\quad$ ad lib., Grand Finale

Disqualification: Transcription by someone other than the original composer. 


\section{FINDINGS}

The process of finding works with specific instrumentation is difficult. In searching numerous webpages and online catalogs, very few have a system that is searchable according to the instruments employed in certain works. At the beginning of this research project, I was aware of a handful of compositions that fit within this category, learning of these by having played them or speaking to others that had either played or conducted them. The Wind Repertory Project database was very helpful as an initial search as their page can be searched by instrumentation through keywords. However, as a work in progress, many pieces, composers, and complete instrumentations do not yet exist.

Few publisher websites have the availability of a search engine that will search the instrumentation of a piece. Many, under the heading of instrumentation, list concert band. If one is fortunate enough to find a title with a score preview, an instrumentation may or may not be accessible. The accuracy of the instrumentation on some of these websites has been found to be not entirely accurate, as if a generic concert band instrumentation were applied to the work based on its classification.

The Music Publisher Association of the Unites States (MPA) ${ }^{9}$ maintains an online directory of over 500 "publishers" from the United States as well as a number of international contacts. While this seems to be a very large number of publishers that can be contacted, there is a problem with classification of different types of publisher. Publisher in this case can mean one that produces print music or publications for ensembles, or it could refer to music publishers who publish songs and records to the music industry. Without a way to filter the directory, the researcher is left to visit each listing's website in order to determine each listing's category.

\footnotetext{
9 "Music Publishers Association of the Unites States - Publisher and Imprint Directory," last accessed May 5, 2019, http://www.mpa.org/directory/.
} 
Of the 541 publishing companies compiled from the MPA Director and other online searches, $210(38 \%)$ were identified as publishers of items other than print music. The remaining 331 publishers were contacted via email regarding their publications in order to identify works that fit the study. Of the 331 publishers contacted, 25 (7.5\%) responded that they had this type of work in their catalog. Of the remaining, $102(31 \%)$ responded that they did not have this type of music or that they did not have the means to search through their catalog to identify these works. Of the 331 identified publishers, 204 (61.5\%) did not respond to the email, were marked "unable to contact" because accurate contact information was not available, or they could not be reached after multiple attempts. Some of these would be later identified as having these types of works in online searches, but are still marked as "unable to contact." Each of these publishers are categorized and listed in the appropriate appendices.

Another finding in this research study was the number of publishers who are now represented by larger publishing companies. Although still listed in the MPA, many are no longer publishing works and have sold their publishing rights to larger companies. One publisher still listed in the MPA directory responded that they had not published music for over ten years. Some indicated that their specialty was choral music or jazz music and had no publications for concert band at all. Many responses indicated that their publications were now produced by companies such as Hal Leonard, Carl Fischer, or any number of larger companies. For example, the J.W. Pepper website ${ }^{10}$ lists 50 publishers that they now represent in their catalog. A category system to identify the publishing type of each entry and even a searchable listing of the imprints held by each company within the directory would be very helpful to MPA members and those utilizing this service.

\footnotetext{
10 “J.W. Pepper - Shop by Sheet Music Publisher," last accessed May 5, 2019, http://www.jwpepper.com/sheetmusic/shop-by-publisher.jsp
} 
Looking away from the larger publishers, many composers are now publishing their own works, distributing either hard copies or many through electronic delivery where ensembles print music on their own. The websites for the individual composers tend to have much more information, including complete instrumentation, background, and program notes for each piece. Contact information leads directly to the composer, many of whom were gracious to provide perusal scores for evaluation in this study. This does, however, create a hardship when searching for new music in a larger catalog. Individual compositions are not often included and, unless there is already a familiarity with the composition, composer, or his/her website, one will not find their works very easily.

The initial scope of this project was to provide an exhaustive listing of all music for concert band that included organ within the instrumentation. However, due to the number of pieces created each day that are not yet catalogued, lack of ability to completely search instrumentation for all works and publications, and the absence of an exhaustive listing of worldwide publishers, corporate or private, there certainly are many more pieces in this category to be discovered. This can be a start for conductors wanting to incorporate the use of the organ they may find in their concert venue.

\section{AREAS FOR FURTHER RESEARCH}

Knowing that there remains a possibility for concert band works that include organ to exist in smaller, international, or individual publishing companies, there is still room for collection of data in this area. The difficulties in locating these works still remain with the limited accessibility to instrumentation in databases or websites and a clear listing of publishers that print music for the concert band either exclusively or within their catalog. A compilation of 
all publishers and their type of publication would prove to be very beneficial in projects like these.

The Wind Repertory Project has made great strides in creating a searchable database of these compositions with a myriad of compositions listed. However, one doesn't have to look hard to find missing pieces, composers, and incomplete information. The Wind Repertory Project depends on contributions of conductors, directors, and students to complete information and update entries as needed. Information is always needed to fill the gaps and to make sure that new compositions are constantly being added. If everyone, including publishers from small to large were on board with this project, it could truly become a comprehensive database.

One blindsiding factor in this research was the inability of certain publishing companies to be able to search and find these works within their catalog. Some would simply reply that they had no way of finding this information on the limited system with which they were working. A quick change of database program or web program that is searchable with these holdings would be of great benefit. How would one find a concert band piece that featured solo trumpet? Unless the composer puts this information in the title, it could prove very difficult. The more accessible these compositions are, the more chance they have of being performed.

Ultimately, I am overwhelmed by the number of pieces that this study has brought to light that were unknown to me or any of my colleagues. In the way of further research, a means of categorizing these works so they are easier to find could possibly ensure their continued performance and give composers reason to write even more works for this specialized area. For those conductors who find themselves with a quality organ (or a suitable substitute), I would hope that this document would be of some assistance in selecting pieces that provide performers 
and audience members alike the remarkable musical experience that comes from the effective combination of concert band and organ. 


\section{APPENDICES}




\section{APPENDIX I \\ Research Invitation Letter Sent to Composers}

\section{WestVirginiaUniversity}

March 18, 2019

Matthew J. McCurry

Creative Arts Center Suite 2101-C

School of Music

1436 Evansdale Drive

Morgantown, WV 26505

Dear [composer],

At present, should band conductors find themselves in a venue with a quality organ, there is not an existing document to aid in finding wind band literature that includes organ within the instrumentation. Through preliminary research, you have been identified as a composer who has occasionally included the organ in your compositions for concert band. I am currently a graduate student at West Virginia University conducting a research study entitled The Inclusion of Organ in the Concert Band Instrumentation with an Annotated Listing of Original Works for Concert Band and Organ. In addition to the annotated listing of works, I would like to include composers' views on the inclusion of organ within the instrumentation as well as their thoughts on omission or substitution of the organ part. Would you consider completing a very brief questionnaire to provide your thoughts on this subject?

There is a link included at the bottom of this letter (or email) that will take you to the questionnaire. Since your time is very valuable, the questionnaire is intended to take 10-15 minutes for you to complete. Participation is voluntary and you may refuse to continue participation at any time. If you choose to participate, your responses may be used in the final publication of the project, however, none of the responses will be connected to any identifying information. Copies of the project will be distributed to my Doctoral Committee as well as the West Virginia University Library Electronic Thesis and Dissertations for standard distribution.

If you have any questions about this research study, you can call Dr. Scott Tobias, Director of Bands, West Virginia University at 304-293-3097. If you have any questions about your rights as a research participant, you can call the West Virginia University Institutional Review Board at 304-293-7073 and reference IRB\# 1903503171.

Thank you for your time and for assisting me in these educational endeavors.

Sincerely,

Matthew J. McCurry

matthew.mccurry@mail.wvu.edu

304-293-3097

PLEASE CLICK THE FOLLOWING LINK TO PARTICIPATE IN THE QUESTIONNAIRE: \{SURVEY LINK\} 


\section{The Inclusion of Organ Within the Concert Band Instrumentation}

Dear participant,

At present, should band conductors find themselves in a venue with a quality organ, there is not an existing document to aid in finding wind band literature that includes organ within the instrumentation. Through preliminary research, you have been identified as a composer who has occasionally included the organ in your compositions for concert band. I am currently a graduate student at West Virginia University conducting a research study entitled "The Inclusion of Organ in the Concert Band Instrumentation with an Annotated Listing of Original Works for Concert Band and Organ." In addition to the annotated listing of works, I would like to include composers' views on the inclusion of organ within the instrumentation as well as their thoughts on omission or substitution of the organ part. Would you consider completing a very brief questionnaire to provide your thoughts on this subject?

Since your time is very valuable, the questionnaire is intended to take $10-15$ minutes for you to complete. Participation is voluntary and you may refuse to continue participation at any time. If you choose to participate, your responses may be used in the final publication of the project, however, none of the responses will be connected to any identifying information. Copies of the project will be distributed to my Doctoral Committee as well as the West Virginia University Library Electronic Thesis and Dissertations for standard distribution.

If you have any questions about this research study, you can call Dr. Scott Tobias, Director of Bands, West Virginia University at 304-293-3097. If you have any questions about your rights as a research participant, you can call the West Virginia University Institutional Review Board at 304-293-7073 and reference IRB\# 1903503171.

Thank you for your time and for assisting me in these educational endeavors.

Sincerely,

Matthew J. McCurry

matthew.mccurry@mail.wvu.edu

304-293-3097

NEXT

Never submit passwords through Google Forms.

\section{Page 1}




\section{The Inclusion of Organ Within the Concert Band Instrumentation}

\section{Questionnaire}

Please answer the following questions in as much detail as possible. In order to keep the questionnaire anonymous, please do not use any identifying information in your answers.

What does the inclusion of the organ within the concert band instrumentation add to the overall composition?

Your answer

When a conductor is choosing music for a performance and there is not an organ available (electronic or pipe), would you consider a synthesized organ sound a suitable substitution?

Your answer

Are there situations where substitution would not be acceptable and omission would be preferred?

Your answer

Does omission of the organ part take away from the original work as it was intended?

Your answer

BACK

NEXT

Never submit passwords through Google Forms.

Page 2 


\section{The Inclusion of Organ Within the Concert Band Instrumentation}

* Required

\section{Thank you!}

\section{Final Submission *}

By checking this box, I am voluntarily participating in this questionnaire and giving consent for my responses to be used in the final publication. I have not been identified in any way in this process.

\section{Page 3}




\section{APPENDIX II}

Publishers with works for Concert Band and Organ (with or without response)

Alliance Publications, Inc.

apimusic.org

American Composers Alliance

composers.com

Amis Musical Circle*

amismusicalcircle.com

Amstel Publications*

halleonard.com

Ayotte Custom Music

ayottemusic.com

Bärenreiter Music Corporation*

baerenreiter.com

Bill Holab Music

billholabmusic.com

Boosey \& Hawkes*

boosey.com

Brett Abigaña Music*

brettabigana.com

C. Alan Publications*

c-alanpublications.com

C.F. Peters*

edition-peters.com

C.L. Barnhouse*

barnhouse.com

Carl Fischer*

carlfischer.com

De Haske Publications

halleonard.com
European American Music Dist.

eamdc.com

F.J.H. Music Company

fjhmusic.com

Freundworks Publishing*

donfreund.com

Hal Leonard Music

halleonard.com

J.W. Pepper*

jwpepper.com

Jesse Ayers Music

jesseayers.com

Kevin Day Music*

kevindaymusic.com

Knightwind Music

knightwindmusic.com

Ludwig-Masters Publications*

ludwigmasters.com

Maecenas Music*

maecenasmusic.co.uk

Manhattan Beach Music

manhattanbeachmusic.com

Markowski Creative (ASCAP)

michaelmarkowski.com

Maslanka Press

maslankapress.com

MopsMusic

mopsmusic.com 
Murphy Music Press*

murphymusicpress.com

Musica Propria, Inc.

musicapropria.com

Music Sales Corporation

musicsales.com

Musikproduktion Höflich*

muiskmph.de

Neil A. Kjos Music Company*

kjos.com

Peer Music Ltd.*

peermusic.com

Piquant Press*

piquantpress.com

Schott Music Corporation

en.schott-music.com

eamdc.com

Stephen Melillo, Stormworks

www.stormworld.com

Stephenson Music

composerjim.com

Subito Music Publishing

subitomusic.com

T.U.X. People's Music

tuxpeoplesmusic.com

Theodore Front Musical Literature

tfront.com

TRN Music Publisher

trnmusic.com

Tyler Harrison Music

tylerharrisonmusic.com
Western International Music

wiminc.com

Wingert-Jones Publications

wjpublications.com $/$ wj

* Publisher had works for Concert Band and Organ found through other research. 


\section{APPENDIX III}

\section{Publishers responding with $\mathrm{NO}$ works for Concert Band and Organ}

A-R Editions, Inc.

Alcove Music Publications

Allaire Music Publications

Alpha Major

American Institute of Musicology

Arsis Press

Art of Sound Music, LLC

Baerenreiter Music Corporation

Barton Rhodes Press

Beckenhorst Press, Inc.

Bob-A-Lew Music

Boosey \& Hawkes, Inc.

Brodt Music Company

Broude Brothers Limited (Closed)

Brolga Music Publishing Company

Buckthorn Music Press

C. Harvey Publications

Calabrese Brothers Music, LLC

Clarus Music, Ltd.

Colla Voce Music, Inc

Concordia Publishing House

Darcey Press

David E. Smith Publications

Doug Beach Music

Dragon Music Company

ECS Publishing

Edition Peters

Eighth Note Publications
Eldridge Publishing Co. Inc.

Elkin Music International

Falls House Press

Farm Lake Music

Four Moons Music Publishing

Galaxy Music Notes

GIA Publications, Inc.

Grand Mesa Music Publishers

Green Shadow Music

Hope Publishing Company

Hummingbird Press

International Church Publications

Jan-Lee Music

Jenson Publications

Kandinsky Press

Kendor Music, Inc.

Kithara Editions

Lake State Publications

Leiber and Stoller

Leonard Bernstein Music Publishing

Lillenas Publishing Company

Lombardo Music Publications

Luck’s Music Library Inc.

Manduca Music Publications

Manna Music, Inc.

Maslanka Press

Meechan Music

Mel Bay Publications, Inc. 
Meredith Music Publications

Millennium Composers Initiative

MMB Music, Inc (Closed)

MorningStar Music

Ned Gerhart Publications

Neil A. Kjos Music Company

Noble Music Company

Northeastern Music Publications

OCP Publications

Octave Music Publishing

Offbeat Publishing

OMI Old Manuscripts \& Incunabula

OnlineSheetMusic.com

Oxford Press

Paraclete Press

Pavane Publishing

Phoebus Publications

Pomus Songs, Inc

Print Music Source

Queenwood Publications

Rainwater Music Company

Santa Barbara Music Publishing

Select-a-Press

Shawnee Press

Silver Clef Music

Sony / ATV Music Publishing

Sound Music Publications

Southern Music Company

Stainer \& Bell Ltd.

T.D. Ellis Music Publishing

The Fox Music Group
The Newmatic Press

Theodore Presser Company

Thomas C. Stangland Company

Thorpe Music Publishing

Three-Two Music Publishing

Transcontinental Music Publications

Transition Music Company

Trillenium Music Company

Triplo Press

Tritone Press \& Tenuto Publications

Vanderbilt Music Co.

We Three Music Publishing, Inc.

Window Music Publishing Co., Inc.

Woodsong Publishing

Yelton Rhodes Music Publishers 


\section{APPENDIX IV}

Publishers that are marked "Unable to Contact" (No response or inadequate information)

Air Deluxe Music Group

Alfred Music

Alry Publications

Amazing Music World

Amherst Early Music

Anglo-American Music Publishers

Are-Gee-Bee Music, Inc.

Artists in Ministry

Atlan-Dec Music Publishers

Azevedo Music

Barton Music \& Affiliates

Beckie Publishing Co., Inc.

Belmont Music Publishers

Benny Davis Music

Berklee Media

Best-Of-British-Music.com

Bill Berends Music Publishing

Bill Edwards Publishing

Black Squirrel Music, Inc.

Blue Dot Composer Collective

BMG Music Publishing, Nashville

Boelke-Bomart/Mobart Music Publishers

Bonded Music
Brass Press

BrassHeart Music

Bravo Music

Brazilian Music Publications

Breitkopf \& Haertel

Brentwood-Benson Music Publishing, Inc.

Bridgeport Music

Brumley Music

Buckhorn Music Publishing, Inc.

Butterfly Fuschia Music Co. (BFMC)

C. Alan Publications

C.F. Peters Corp.

C.L. Barnhouse Company

Cambiata Press

Canadian Music Center

Carl Fischer, LLC

Carlin America, Inc.

Celebrations Unlimited Music Publishers

Centerstream Publishing LLC

Charles Colin Publications

Chartbound Music Publications Ltd.

Choristers Guild 
Church Publishing Inc.

ClarNan Editions

Claude T. Smith Publications

Colter's Corral Music

Common Mode, Inc.

Consort Press

Curnow Music Press, Inc.

Dantalian, Inc.

David Rose Publishing Co.

Deep Listening Publications

Define Something In Nothing Music

Dennis E Meyer Music

Disney Music Publishing

Dorn Publications, Inc.

Dreamfire Music, Inc

Dunvagen Music Publishers, Inc.

Eaton Music, Inc.

Editions Orphee, Inc.

Edward B. Marks Music Company (searchable through Hal Leonard)

Edwin F. Kalmus \& Company Inc.

Engraver's Mark Music

Ensemble Publications

Fame Publishing Co., LLC

Fancy Pants Music

Fannin Musical Productions LLC
Filmtrax

Foreign Music Distributors

Fountain Park Music Publishing

Frank E. Warren Music Service

Fred Bock Music Company, Inc.

Funki-Gruv Music

G. Schirmer, Inc. (searchable through Hal Leonard)

Gamble-Huff Music

Gems Music Publications

Glad Music Company

GPG Music

GPS Music Group

Graceful Samba Music

Grandview Island Publishing

Gregmark Music, Inc.

Gulf Wind Music Press

Hallmark Music Company, Inc.

Hazamir Publications

Hildegard Publishing Company

Hillcrest Music Corp.

Hinshaw Music, Inc.

IDG Publishing

IMMA Publishing Co.

International Music Co.

Irving Berlin Music Company 
Irving Mills Music

Iza Music Company

J. S. Sato Music Editions

J.S. Paluch Co./World Library

Publications

J.W. Pepper \& Son, Inc.

Jabez Press, LLC.

Jamie Music Publishing Company

James River Music

Janew Music Publishing

Jay Gold Music Publishing

JC Cantin Publishing Co. LLC

Jerona Music Corp.

Jerry Bock Enterprises

Jewel Music Publishing Co., Inc.

JL Publishing

K. Benyard Music Company

Kelton Publications

Ken Medema/Brier Patch Music

Kent Steel Music Factory

Key Poulan Music

Lauren Keiser Music Publishing

LCS Music Group

LeDor Publishing

Limu Publishing Company

Lorenz Creative Services
Lovebird Music

Lowery Group

Ludwig Masters Publications

Maestro \& Fox Music

Makin Music, Inc.

Maranatha! Music

Maraschino Music Company

Media Press, Inc.

Memory Lane Music Group

Mercer Publications Inc.

Mijen Press

Million \& One Publishing

Mona Lisa Sound

Morning Music Inc.

Morris Music, Inc.

Morton Music Pty Ltd

Mountain Crest Music

Mountain Peak Music

MPL Communications, Inc.

Music Sales Corporation

Music Together LLC

Musica Russica

Musicians Publications

MusicNotes, Inc.

Muzicas Editions 
NDC Editions, Inc.

Neil Larsen Publishing

New West Music \& Publishing, Inc.

Noted for the Record

One Omik Music

Orpheus Publications

Orrganized Sound

Pacific Press Publishing

Peermusic Classical

Piano Producations Press

Prairie Sky Music

Pullara-Tunes

Puna Music Company

Quark Music Group

RBC Music Company Inc.

Review \& Herald Publishing Assoc.

Rolltop Music

Ron Harris Music

Royal Music Publisher

S\&R Music Publishing Company

Schaffner Publishing Company

Scott Music Publications

Scott Tutt Music

Shapiro, Bernstein, \& Company, Inc.

Sierra Music Publications
Smart Chart Music

Somers Music Publications

Songs for the Planet

Songs of the Knight

Sony Pictures Music Group

St. Nicholas Music, Inc.

Steve Reid Productions

Su-Ma Publishing Company

Subito Music Corporation

Tara Publications

TBQ Press

Tempo Press

Teshmusic

Teshuvah Music Inc.

The Bicycle Music Company

The Frederick Harris Music Company

The Lorenz Corporation

Treble C Music

TRO ESSEX (The Richmond Organization)

Tuneworks Music

United Music \& Media Publishers

Universal Edition, Inc.

Universal Music Publishing Group (sold through Hal Leonard)

Up With People 
Vashti Music, Inc.

Vivace Press

Walkerbout Music Group

Waterton Brass Music

Web IV Music Publishing

WesTunes Music Publishing Co.

Wild Rose Publishing Co.

William Grant Still Music

William H. Bauer, Inc.

Zondervan Music Group 